\title{
A hitelszövetkezetek gazdaságélénkítési szerepe Kárpátalján összefüggésben az Egán Ede-terv megvalósításával
}

\author{
BACSÓ RÓBERT ${ }^{1}$ - PATAKI GÁBOR ${ }^{2}$
}

\begin{abstract}
ABSZTRAKT
A tanulmány célja, hogy a kárpátaljai üzleti környezet bemutatásával, valamint egy sajátos szektor (hitelszövetkezetek) kiemelése révén bemutatásra kerüljenek az elmúlt években megjelenő vállalkozások versenyképességét javító magyarországi gazdasági támogatások sajátosságai. A tanulmány készítésének az időszakában még nem áll rendelkezésre olyan mértékú statisztikai adat, hogy egzakt módon bemutassuk a támogatások hatásfokát, viszont az első évek tapasztalatai alapján le tudjuk szúrni azokat a devianciákat, kisebb kiigazításra szükséges elemeket, amelyek javíthatják a tervek megvalósulását. Másik oldalról - s ez jelenti a tanulmány központi súlyát - az a szerzők meglátása, hogy fontos a vissza nem térítendő támogatásokon túl olyan mikro, kvázi szövetkezeti hitelek folyósítása is, ami a gazdaságélénkítés folyamatát önjáróvá teszi, s ezzel hosszabb távra biztosítja a mikro-, kis- és középvállalkozások tôkeellátottságának fokozását. Erre jó eszköz lehet az Ukrajnában már elterjedt, Kárpátalján is honos, de a magyar térségben, napjainkban, nem jellemző hitelszövetkezeti rendszer felélesztése, s a gazdasági rendszerünkbe való beágyazottságának a javítása. E rendszer helyzetértékelését és jövőre vonatkozó elvi javaslatait fogalmazza meg ez az írás.
\end{abstract}

KULCSSZAVAK: Kárpátalja, vállalkozások, hitelszövetkezet, támogatáspolitika, gazdasági hatékonyság, pénzügyi stabilitás.

\section{ABSTRACT}

\section{The economic quickening role of the credit unions related to the execution} of the Egán Ede-plan in Transcarpathia

The purpose of this study was to submit the last years' particularities of the hungarian economical supports in ventures' improvements of competitiveness, representing through the transcarpathian business environment and a specific sector (credit unions). In the period when the study was being carried out there were not such statistic data at service as the efficiency of the supports could have been shown precisely, but in virtue of the first years' experiences those deviances and elements (which need minor corrections) have been clarified which can

\footnotetext{
${ }^{1}$ II. Rákóczi Ferenc Kárpátaljai Magyar Főiskola, tanszékvezető, egyetemi docens.

${ }^{2}$ II. Rákóczi Ferenc Kárpátaljai Magyar Főiskola, tanársegéd.
} 
www. metszetek.unideb.hu

\section{TEMATIKUS TANULMÁNYOK - Kárpátalja társadalma}

improve the plans' fulfilment. On the other hand - which means the central point of the studythe authors' realization is over the non-refundable aids to grant micro or so called co-operative credits which makes independent the economics' process of quickening, which can give a longterm insurance to the capitalization's enhancement of the micro-, small- and medium-sized enterprises (ventures). For this a good tool can be the resurrection of the credit union system and the improvement of the infiltration to our economical system, which is widespread in Ukraine, endemic in Transcarpathia but not peculiar in our hungarian region nowadays. The system's estimate of situation and the principle proposal for the future is drafted in this study.

KEYWORDS: Transcarpathia, enterprises, credit unions, support policy, economic efficiency, financial stability.

\section{Bevezetés}

A kárpátaljai magyarság mindig is változó korszakokat élhetett meg. A térség viharos XX. százada, melyben országok és nagyhatalmak jöttek, majd mentek ${ }^{3}$, a változatos népesség - melyek többnyire békében éltek és élnek egymás mellett -, valamint a periférikus volta miatti gazdasági fejletlenség a lakosságot vagy elvándorlásra, vagy kitartó munkára hívta el. Az elmúlt öt év felgyorsította ezeket a folyamatokat és olyan változások indultak el, melyek korábban sokkal lassabb módon valósultak meg. Nőtt a gazdasági kivándorlás, a fiatalok számára kinyíltak a határok, egyre többen próbálnak szerencsét Nyugat-Európában és szerte a nagyvilágban.

A térség önálló vállalkozói aktivitása jellegzetesen gyenge szintet mutatott. Az emberek vállalkozói hajlama alacsony, mely a politikai, gazdasági, társadalmi bizonytalansággal, a tudatos kineveléssel és egyéb szociális, pszichológiai tényezőkkel összefüggésben érthető meg.

Az elmúlt években viszont olyan lehetőség adódott, ami korábban soha sem. Magyarország Kormánya 2010-től olyan mértékű fejlesztést és hozzáadott értéket vitt a nemzetpolitikába, ami mára már nem csak a kulturális, civil élet számára ad kibontakozási teret, de főleg az Egán Ede gazdaságfejlesztési programon a mikro-, kis- és akár a középvállalkozások számára is olyan mértékű tőkeinjekciót biztosít, ami lehetőséget adhat az alacsony szintű termelékenység leküzdésére, ezáltal az életszínvonal emelésére.

Fontosnak tartjuk, hogy a források felhasználása a lehető leghatékonyabb módon valósuljon meg. Mivel e tanulmány készítésének időpontjában még nem állnak rendelkezésre olyan indikátorok, statisztikai táblák, melyekből egzakt összefüggést tudnánk feltárni, ezért most nem is vállalkozunk arra, hogy a támogatások és a térség gazdasági fejlődése közötti összefüggést feltárjuk.

\footnotetext{
${ }^{3}$ Egy-egy idős ember a falujának elhagyása nélkül 4-5 ország állampolgára lehetett.
} 


\section{TEMATIKUS TANULMÁNYOK - Kárpátalja társadalma}

Jelen tanulmány főleg arra hívja fel a figyelmet, hogy:

- fontos megérteni, vizsgálni és általános helyzetképet bemutatni Kárpátalja vállalkozási, társadalmi, gazdasági szerkezetéről;

- bemutatni - összehasonlítva ukrajnai országos adatokkal -, hogy milyenek a hitelszövetkezetek kialakulásának és jelenkori fejlődésének sajátosságai, ezzel jellemezve a források hosszú távú felhasználásnak és a reálgazdaságban betöltött szerepének hatékonyságjavító eszközét;

- megismerni a magyarországi fejlesztési források elosztásának szerkezetét, sajátosságait;

- javaslatokat tenni arra, hogy miként lehetne javítani a támogatások felhasználásának hatékonyságát;

- kijelölni azokat a további utakat, melyek tudományos munkákon keresztül egzakt válaszokat adhatnak a támogatási rendszer és a térség gazdasági felzárkózása közötti összefüggések megértésében, hibák kijavításában és a hatékonyság növelésében.

\section{A kutatás módszertana, célkitűzése}

A kutatás célja gazdaságtudományi módszerekkel bemutatni a hitelszövetkezetek gazdaságélénkítő szerepét Kárpátalján, kiemelten az Egán Ede-terv (a továbbiakban EET) megvalósulási idejétől számítva.

E cél eléréséhez a következőket kellett elvégeznünk:

- bemutatni a Kárpátalján működő hitelszövetkezetek szerepét a régió gazdaságában;

- összehasonlítani a hitelszövetkezetek pénzügyi mutatóit kárpátaljai és ukrajnai viszonylatban;

- bemutatni a kárpátaljai hitelszövetkezetek pénzügyi stabilitásának fokát és fizetőképességét;

- kiértékelni a hitelszövetkezetek betét- és hitelportfóliójának futamidős eloszlását, mely segít rávilágítani a kárpátaljai forráshiány hosszútávú problémáira;

- általános helyzetértékelést adni az EET pályázati lehetőségeiről, s ezzel bemutatni a megvalósulás első évét.

A kutatást a következő módszerek segítségével végeztük el:

- statisztikai módszerek segítségével komparatív összehasonlítást végeztünk az ukrajnai és kárpátaljai hitelszövetkezetek pénzügyi mutatóiról, valamint bemutattuk szerepüket a régió és az ország gazdaságában;

- korrelációs elemzéssel bemutattuk a valós ok-okozati kapcsolatokat, egyfelől a hitelszövetkezeti hitelezés és az EET finanszírozása, másfelől pedig a mik- 


\section{TEMATIKUS TANULMÁNYOK - Kárpátalja társadalma}

ro- és kisvállalkozások munkahelyteremtése és a termelékenység növekedése között;

- a PEARLS módszer (modell) segítségével kimutattuk a kárpátaljai hitelszövetkezetek pénzügyi stabilitásának fokát és fizetőképességét.

Az Egán Ede Gazdaságfejlesztési program operatív módon nem kínál mikro-hiteleket. A döntéshozók interpretációja az, hogy a jelenlegi ukrajnai hitelezési rendszer nem alkalmas arra, hogy magyar-ukrán államközi gazdaságfejlesztési program keretében biztonságosan és hatékonyan tudja betölteni a szerepét. A tanulmány egyik legfontosabb hasznosulása a jövőben az lehet, hogy felmutat olyan reális konstrukciót, mely alkalmassá teheti az Egán Ede program kiterjesztését mikro-hitelek elindítására. Ennek egyik iránya lehet a hitelszövetkezetek alapítása és feltőkésítése Ukrajnában.

A hitelszövetkezetekkel kapcsolatos tudományos kutatás hozzájárul ahhoz, hogy az elméleti megalapozottságon túl a jövőben gyakorlati hasznosulása is lehessen a térségben működő kis- és középvállalkozások számára, ami az Egán Ede terv kettős finanszírozási természetét (vissza nem térítendő támogatás, valamint a hitelezési konstrukciók ${ }^{4}$ ) figyelembe véve jobban hasznosulhat a vállalkozásfejlesztési támogatás a kárpátaljai magyarság gazdasági fejlődésében.

\section{Kárpátaljai vállalkozások helyzetképe a régió társadalmi-gazdasági viszonyai között}

A kárpátaljai vállalkozások helyzetét egyrészt érdemes történeti kontextuson keresztül vizsgálni, melyből kitűnik, hogy miért alacsony a vállalkozói hajlandóság, milyen negatív pszichés és társadalmi berögződések állnak amögött, hogy a vállalkozóvá válás akadozva valósul meg a helyi társadalomban. Mindenképp vizsgálni kell a gazdasági, társadalmi, jogi viszonyokat, melyek, mint meghatározó tényezők tudják serkenteni, adott esetben pedig rontani az üzleti vállalkozások létrejöttének esélyeit. Ebben a fejezetben, a környezeti hatásokat elemezzük, kezdve az általános demográfiai, geopolitikai és gazdasági helyzet ismertetésével, mely az országot és a régiót jellemzi.

${ }^{4}$ Hitelezés alatt jelenleg nem a mikro - aminek hiányát jeleztük a fentiekben - hanem a közepes és nagykonstrukciók lehetőségét értjük. 
www. metszetek.unideb.hu

\section{TEMATIKUS TANULMÁNYOK - Kárpátalja társadalma}

\section{Társadalmi és gazdasági összetevők}

Kárpátalja Ukrajna legnyugatibb megyéje. Az ország összlakossága 2017. január 1-i becslés ${ }^{5}$ szerint 42,6 millió fö ${ }^{6}$ (Ukrajnai Állami Statisztikai Szolgálat 2017). Kárpátalját 1254400 lakosra becsülték, mely az ország lakosságának 2,7 \%-a, teljes területének pedig 2,1 százalékát teszi ki (az 1. táblázat a megye és az ország adatait hasonlítja össze lakosság, terület, járás, város-falu és GDP összefüggésében).

1. táblázat. Kárpátalja paraméterei Ukrajna relációjában

\begin{tabular}{|c|c|c|c|c|c|c|c|c|c|c|c|c|}
\hline \multirow[b]{2}{*}{ Kárpátalja } & \multicolumn{2}{|c|}{$\begin{array}{c}\text { Lakosság } \\
\text { (millió fó/\%) }\end{array}$} & \multicolumn{2}{|c|}{$\begin{array}{l}\text { Terület } \\
\left(\mathrm{m}^{2} / \%\right)\end{array}$} & \multicolumn{2}{|c|}{$\begin{array}{l}\text { Járások } \\
\text { (db/\%) }\end{array}$} & \multicolumn{2}{|c|}{$\begin{array}{l}\text { Városok } \\
\text { (db/\%) }\end{array}$} & \multicolumn{2}{|c|}{$\begin{array}{l}\text { Falvak } \\
(\mathrm{db} / \%)\end{array}$} & \multicolumn{2}{|c|}{$\begin{array}{c}\text { Egy före jutó } \\
G D P^{*}(U A H, \%)\end{array}$} \\
\hline & 1,2544 & 2,94 & 12752 & 2,11 & 13 & 2,65 & 11 & 2,39 & 578 & 2,04 & 22989 & 81,01 \\
\hline Ukrajna & \multicolumn{2}{|c|}{42,6} & \multicolumn{2}{|c|}{603500} & \multicolumn{2}{|c|}{490} & \multicolumn{2}{|c|}{460} & \multicolumn{2}{|c|}{28377} & \multicolumn{2}{|c|}{46413} \\
\hline
\end{tabular}

Forrás: Ukrajnai Állami Statisztikai Szolgálat, 2017. www.ukrstat.gov.ua

*2015-ös év adata.

A táblázatból látható, hogy az egy főre jutó GDP tekintetében az országos átlag 81 százalékát éri el Kárpátalja teljesítménye a 2016-os évben. Infláció tekintetében viszont jobb értékekkel rendelkezik megyénk, ami az utóbbi évek erős fogyasztói árváltozását szemlélve és az országot sújtó hatása miatt fontos (2. táblázat).

2. táblázat. Fogyasztói árindex alakulása

Ukrajnában és Kárpátalján 2010-2016 időszakában (CPI)

\begin{tabular}{|l|c|c|c|c|c|}
\hline & 2010 & 2013 & 2014 & 2015 & 2016 \\
\hline Kárpátalja & 108 & 98,8 & 111,1 & 146,2 & 110,6 \\
\hline Ukrajna & 109,4 & 99,7 & 112,1 & 148,7 & 113,9 \\
\hline Eltérés & $-1,4$ & $-0,9$ & -1 & $-2,5$ & $-3,3$ \\
\hline
\end{tabular}

Forrás: Ukrajnai Állami Statisztikai Szolgálat, 2017. www.ukrstat.gov.ua

Mind megyei, mind országos szinten jelentős inflációról beszélhetünk, főleg a 2015-ös évben, mely valamelyest mérséklődött tavaly.

Üzleti vállalkozások tekintetében Kárpátalja sereghajtónak számít az országon belül. 1000 lakosra számítva csupán 17 bejegyzett profitorientált vállalkozásról beszélhetünk, míg ezzel szemben a fóváros pedig 87 vállalkozás/1000 fő mutatóval bír (Ukrajnai Állami Statisztikai Szolgálat 2017).

\footnotetext{
${ }^{5}$ Hivatalos népszámlálás utoljára 2001-ben volt az országban. Így mint országos, mint megyei relációba csupán statisztikai becslések állnak a rendelkezésünkre.

${ }^{6}$ Az érték magában foglalja Krimet és a Donyeck-medencét.
} 


\section{TEMATIKUS TANULMÁNYOK - Kárpátalja társadalma}

Az ipari termelés volumene az előző év százalékában kifejezve országos szinten az utóbbi évben némi növekedést mutatott $(2,6 \%)$, viszont azt megelőzően a kelet-ukrajnai konfliktusok hatására jelentős visszaesés történt (-5-től -13\%-os szinten). Kárpátalján elég változatos értékeket mutat ez az index (lásd az 1. ábra).

1. ábra. Ukrajna és Kárpátalja ipari termelési indexének alakulása

2010-2016 közötti időszakban (\%)

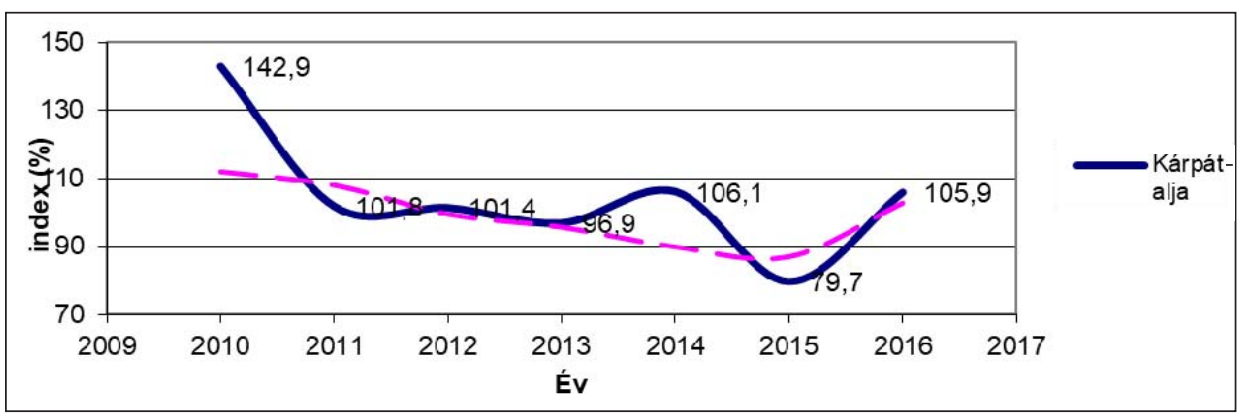

Forrás: Ukrajnai Állami Statisztikai Szolgálat, 2017. www.ukrstat.gov.ua

A megye lakossága valamivel több, mint 1,2 millió fő, melynek 63 százaléka falvakban él (elmúlt két évtizedben valamelyest növekedett a városi lakosság száma, de még ma is inkább a vidéki életforma dominál).

A születési és halálozási statisztikákat figyelve országos szinten folyamatos népesség csökkenés tapasztalható (2010-től 150-200 ezer fővel kevesebb gyermek születik, mint ahány ember elhalálozik; 2016-ban Ukrajnában 186,6 ezer fős csökkenés volt tapasztalható). Az előző évben egyedül Kárpátalján haladta meg a születések száma az elhalálozásokét (+601fő). Migráció tekintetében megyénkben (igazolva a tapasztalati tényeket), erősödött az elvándorlás, bár a hivatalos érték véleményünk szerint - alatta marad a valós adatoknak (982 fő 2016-ban, Ukrajnai Állami Statisztikai Szolgálat 2017).

A munkastatisztikákat figyelve országos szinten egyre csökken a gazdaságilag aktív, munkaképes lakosság száma (2016-ban 85,6 százaléka a 2010-es bázisévnek). Tehát a fő problémát országos szinten nem is annyira a munkanélküliek abszolút száma, hanem a foglalkoztatottak alacsony aránya jelenti. 2016-ban a hivatalos munkanélküliségi ráta 9,3\%, viszont ehhez képest Kárpátalján csak 5,9\%.

Az elmúlt években, nominális formában folyamatosan növekedett az átlagbér (20-23\%-os mértékben), viszont az előző három év összehasonlításában egyedül tavaly nőtt reál értelemben (+9\%). 2015-ben a bérek vásárló értéke csökkent 20,2\%al, 2014-ben pedig 6,5\%-kal az előző évhez viszonyítva. 


\section{TEMATIKUS TANULMÁNYOK - Kárpátalja társadalma}

Kárpátalján a nominális bérnövekedés magasabb volt 2016-ban, mint az országos átlag (127,1\%-a az előző évinek). Véleményünk szerint ez a növekedés főleg annak tudható be, hogy a megyénkben a vállalkozóknak főleg nem a belső munkaerőpiaci kereslettel kell versenyeznie, hanem a nyugati országok által kínált bérszínvonallal, ami bérfelhajtó hatással bír. Ez növeli a vállalkozások termelési önköltségét, s amíg ez nem párosul technológiai fejlesztéssel - ennek értelmében hatékonyságnövekedéssel -, a helyi termelők nehezen tudják kigazdálkodni a magasabb béreket.

Az oktatási rendszer kérdése Ukrajnában és vele együtt Kárpátalján jelentős problémákkal küzd. Jelen tanulmány keretein belül nem térünk ki a nyelvtörvény és egyéb adminisztratív korlátok okozta károkra. A statisztikák alapján elmondható, hogy nemzetiségtől függetlenül folyamatosan csökken a tovább tanulók aránya, jócskán elmarad a szakiskolai végzettséggel rendelkezők száma is ahhoz képest, amit a gazdaság egészséges szerkezete igényelne. A magyar diákok rendszerint Magyarországon, de az ukránság jelentős része is nyugat-európai alapképzésre iratkozik be (esetükben főleg Csehország és Lengyelország a fó célhely). E tanulók túlnyomó többsége már nem az ország munkaerőpiacát gazdagítja, s így tovább nő a kiemelt, magas hozzáadott értékú ágazatok degradálási folyamata. A statisztikai hivatal 2017-es jelentése alapján (Ukrajnai Állami Statisztikai Szolgálat 2017) 2010/11es tanévben a 3-4. akkreditációjó felsőoktatási intézményekbe jelentkezők száma még 2129,8 ezer tanuló volt, addig az előző tanévre beiratkozottak száma már csak 1369,4 ezer fö (35,7\%-os csökkenés).

\section{Üzleti vállalkozások helyzete Kárpátalján}

A vállalkozások helyzete mindig is ellentmondásos volt a régiónkban. Köznyelvi beszélgetésben egyrészt a lehetetlen, kaotikus rendszerek, másrészt a lehetőségek halmaza fogalmazódik meg azok fejében, akik e területen tevékenykednek. Jelen alfejezetben a hivatalos statisztikák, valamint a közelmúltban empirikus módszerekkel mért magyar vállalkozási helyzetet feltáró kutatás alapján kívánunk általános képet festeni a megyénk vállalkozási helyzetéről.

\section{STATISZTIKAI ELEMZÉS}

A kárpátaljai statisztikai hivatal adatai alapján 2016-ban 306369 vállalkozás múködik, melynek elenyésző hányada nagyvállalat $(0,1 \%)$, középvállalkozás 4,9 százalék, a többi kisvállalkozások kategóriáját bővíti (291 154 db, 95\%). A kisvállalkozások dominanciáját mutatja, hogy az utóbbi kategória további 80,8 \%-a mikrovállalkozás. A nagyvállalatok (383 db) 54 százaléka az iparban tevékenykedik, 30,3\% pedig a nagykereskedelem és a gépjárműipari szolgáltatások ágazatában működik. A mikro- 
www. metszetek.unideb.hu

\section{TEMATIKUS TANULMÁNYOK - Kárpátalja társadalma}

és kisvállalkozások többsége az agráriumban található (14,5\%), illetve megoszlik a kiskereskedelem és egyéb ágazatok között.

Érdemes még megvizsgálni a magyar lakta területek vállalkozási szokásait a statisztikák tükrében (Kárpátaljai Állami Statisztikai Szolgálat 2017).

3. táblázat. Kárpátaljai vállalkozások tevékenységének főbb mutatói 2016-ban

\begin{tabular}{|c|c|c|c|c|c|c|c|c|c|c|}
\hline \multirow[t]{2}{*}{$\begin{array}{l}\text { Területi } \\
\text { egység }\end{array}$} & \multicolumn{2}{|c|}{$\begin{array}{l}\text { Vállalkozók } \\
\text { száma }\end{array}$} & \multicolumn{2}{|c|}{$\begin{array}{l}\text { Munkaválla- } \\
\text { lók száma }\end{array}$} & \multicolumn{2}{|c|}{$\begin{array}{l}\text { Bérmunkások } \\
\text { száma (fó) }\end{array}$} & \multicolumn{2}{|c|}{ Bérkifizetések } & \multicolumn{2}{|c|}{$\begin{array}{l}\text { Értékesített } \\
\text { termékek } \\
\text { árbevétele }\end{array}$} \\
\hline & $\mathrm{db}$ & $\%$ & fő & $\%$ & fő & $\%$ & ezer UAH & $\%$ & ezer UAH & $\%$ \\
\hline Kárpátalja & 5058 & 100,0 & 80386 & 100,0 & 78178 & 100,0 & 4164644 & 100,0 & 40595224 & 100,0 \\
\hline Ungvár & 1457 & 28,8 & 16637 & 20,7 & 16059 & 20,5 & 664468 & 16,0 & 9784149 & 24,1 \\
\hline Munkács & 610 & 12,1 & 14890 & 18,5 & 14750 & 18,9 & 801406 & 19,2 & 9931118 & 24,5 \\
\hline Beregszász & 173 & 3,4 & 4156 & 5,2 & 4077 & 5,2 & 196976 & 4,7 & 810218 & 2,0 \\
\hline $\begin{array}{l}\text { Beregszászi } \\
\text { járás }\end{array}$ & 250 & 4,9 & 1798 & 2,2 & 1622 & 2,1 & 93408 & 2,2 & 466527 & 1,1 \\
\hline $\begin{array}{l}\text { Munkácsi } \\
\text { járás }\end{array}$ & 328 & 6,5 & 4687 & 5,8 & 4493 & 5,7 & 192365 & 4,6 & 2526399 & 6,2 \\
\hline $\begin{array}{l}\text { Ungvári } \\
\text { járás }\end{array}$ & 458 & 9,1 & 10104 & 12,6 & 9831 & 12,6 & 732911 & 17,6 & 7820887 & 19,3 \\
\hline $\begin{array}{l}\text { Szöllősi } \\
\text { járás }\end{array}$ & 174 & 3,4 & 3911 & 4,9 & 3847 & 4,9 & 189666 & 4,6 & 1246345 & 3,1 \\
\hline
\end{tabular}

Forrás: Kárpátaljai Állami Statisztikai Szolgálat, 2017 (kivonat a teljes adattáblából).

A táblázatból látható, hogy a megyeközpontnak van a legjelentősebb gazdasági ereje (a vállalkozások közel 29\%-a található meg Ungváron). A magyar lakta járások tekintetében szintén az ungvári járás vezet, majd követi a munkácsi és a beregszászi, végül pedig a nagyszőlősi járás következik. Munkavállalás tekintetében a vállalkozások súlyarányához képest magasabb a munkavállalók aránya, ami arra utal, hogy több a közepes és nagyobb vállalat, így azt átlagos alkalmazotti létszám is. Bérek tekintetében Munkács város a legjelentősebb, ezzel szemben a beregszászi járásban a legalacsonyabb az összbérkifizetés száma. Ezt követi az értékesítés árbevételének az alakulása is, sajnos a „legmagyarabb járásban” a legalacsonyabb ez az érték (1,1\%-a megyei összértéknek, míg Munkács közel negyedét viszi a teljes árbevételnek).

A statisztikák alapján látható, hogy Kárpátalja gazdasági ereje nem oszlik meg egyenletes formában a járások között. Külön nem tértünk ki minden járásra, viszont látható, hogy a gazdaságilag két jelentős város (Ungvár és Munkács) körül koncentrálódik az ipar, valamint a hatékony, magas termelési értékkel bíró vállalkozások, 


\section{TEMATIKUS TANULMÁNYOK - Kárpátalja társadalma}

míg a magyarok által lakott térség, főleg vidéki adottságaiból adódóan alacsony vállalkozói létszámmal és hozzáadott értékủ termeléssel bír. Főleg ez utóbbi okozza az alacsony béreket és ezt szembe állítva a magyarok külföldi munkavállalási lehetőségeivel rögtön levonható a következtetés, hogy az utóbb 5 évben miért erősödött a térségben a gazdasági kivándorlás és a külföldi munkavállalás. Statisztikák nem állnak módunkban e tendenciák pontos leírására, viszont helyzetértékelések születtek az elmúlt években, melyek következtetéseivel folytatjuk a továbbiakban.

\section{FIATAL VÁLLALKOZÓK ÉS CSALÁDI VÁLLALKOZÁSOK HELYZETE KÁRPÁTALJÁN}

A Hétfa Kutatóintézet által 2016-ban megjelentett Megkapaszkodás, gyarapodás, bátorítás c. kutatás a külhoni régió magyar területein vizsgálta a vállalkozások helyzetét, főleg a fiatal (40 év alatti) vállalkozók sajátosságait (Czaller - Csite - Geambașu 2016).

A tanulmány egyik következtetése, hogy a térségben Kárpátalján vállalkoznak fiatalként a legalacsonyabb számban. Régiótól függetlenül a fiatal vállalkozók általában 20 -as éveik végén, 30 -as éveik elején járnak, átlagosan egy gyermeket nevelnek, gyakori a felsőfokú végzettség, s a megvalósulásban a személyes, családi és közösségi erőfeszítések dominánsak. A kivándorlás tekintetében sokkal jobb mutatókkal bírnak azok a fiatalok, akik vállalkozásba kezdtek, mint akik munkavállalóként tevékenykednek adott régióban.

A tanulmány vizsgálta a vállalkozások attitűdjét az adott ország adminisztratív szabályozási környezete kapcsán is. A 185 országot vizsgáló kutatás Ukrajnát a közép-kelet európai régióban az utolsó helyre pozícionálta, összességében pedig a 85. helyen áll (Czaller - Csite - Geambașu 2016 a www.doingbusiness.org nyomán). Az államműködéstől a vállalkozók azt várják el, hogy ne ártson. „Már »jónak« értékelik azt, ha nem akadályozzák az állami hatóságok a mindennapi nyugodt munkavégzést. Egyes térségekben (pl. Székelyföld) az állami fellépés kimondottan eröszakos, büntetö jellegü, míg másutt ( $p l$. Felvidék) elnézőbb a szabálytalanságokkal szemben. Az állammúködés minőségének javulásáról leginkább Kárpátalján és a Délvidéken számoltak be a vállalkozók." (Czaller - Csite - Geambașu 2016: n.a.)

Arra a kérdésre adott válasz, hogy inkább előny-e vagy hátrány magyar nemzetiségűnek lenni az adott többségi nemzet országában, a többi régióhoz képest viszonylag rosszabb a helyzet Kárpátalján, ugyanis a kérdőíves kutatás eredményeként 46\% mondta azt, hogy inkább rosszabbak a magyarok lehetőségei, 36\% szerint nincs különbség és nem volt olyan, aki szerint jobbak. Az idei év felmérése némi elmozdulást mutatnak, amely arra enged következtetni, hogy a magyarországi gazdasági támogatások hatására a vállalkozói szféra is érzi annak pozitív előnyeit, hogy érdemes magyarként helyben boldogulni. Az idei évvel kapcsolatos tanulmányok 
www. metszetek.unideb.hu

\section{TEMATIKUS TANULMÁNYOK - Kárpátalja társadalma}

megjelenés alatt állnak, így a változások tendenciáit egy következő tanulmány keretein belül tudjuk majd tovább vizsgálni és a hatásokat értelmezni.

\section{A KÁRPÁTALJAI HITELSZÖVETKEZETEK TEVÉKENYSÉGÉNEK BEMUTATÁSA, HITELPORTFÓLIÓJÁNAK ELEMZÉSE}

Kárpátalján a szövetkezeti hitelintézetek - más ukrajnai megyékhez viszonyítva elég hosszú múltra tekintenek vissza, kialakulásuk a 19. század második felére, az Osztrák-Magyar Monarchia idejére tehető. A szovjet rendszer idejében (1945-től) a szövetkezeti hitelintézetek minden eszköze államosításra került. A szövetkezeti mozgalom újjászületése Kárpátalján csak a 20. század 90-es éveiben kezdődött meg. Ezért állapíthatjuk meg azt, hogy a régióban a szövetkezeti hitelintézetek saját történelemmel és bizonyos tekintetben jellegzetes működési hagyományrendszerrel rendelkeznek.

Megyénkben a hitelintézetek működésének állami szabályozási feladatait csupán egy személy - a pénzügyi szolgáltatások piacainak állami szabályozásáért felelős Nemzeti Bizottság munkatársa látja el, mely egyidejűleg minden egyéb nem banki pénzügyi intézmény működését is felügyeli a régióban (biztosítási cégek, zálogházak, pénzügyi vállalkozások stb.) A felügyelő hatóság megyei kirendeltségeinek hiánya a régióban hátrányosan befolyásolja a nem banki pénzügyi szolgáltatások piacán a megfelelő fogyasztóvédelmet, mivel azoknak jogsértés esetén panaszaikkal a Nemzeti Bizottság Kijevben található központi irodájához kell fordulniuk. Így nem meglepő, hogy vannak olyan javaslatok, melyek szerint érdemes lenne a Nemzeti Bizottságot beolvasztani az Ukrán Nemzeti Bankba (UNB), mivel így a fogyasztók panaszaikkal közvetlenül kereshetnék a Nemzeti Bank regionális kirendeltségeit.

2016 elején Kárpátalján 15 szövetkezeti hitelintézet és 21 hitelszövetkezeti fiók folytatott tevékenységet. Figyelemre méltó, hogy a térségben nem működött egyetlen megyén kívüli székhellyel rendelkező hitelszövetkezet sem. A „Mrija” hitelszövetkezet - a pénzügyi intézmények állami nyilvántartásából történő kizárásáig - volt az egyetlen olyan hitelszövetkezeti intézmény a megyében, amely a megyén kívül is nyújtott szolgáltatásokat, és annak kiterjedt rendszere 33 mérleggel rendelkező fiók-egységet, illetve 96 értékesítési pontot számlált Ukrajna szerte. A kárpátaljai hitelszövetkezeti rendszer alanyainak általános szerkezeti felépítése az 4. táblázatban látható.

Megjegyzendő, hogy jelenleg a statisztikai hivataloknál összesen 33 hitelszövetkezet regisztrációját lehet fellelni. Ugyanakkor az ukrán állami pénzügyi intézmények nyilvántartásában csak 15 hitelszövetkezetről van információ, ami arra enged következtetni, hogy 18 hitelszövetkezet felszámolás alatt áll, vagy csődeljárás indult ellene. Az ilyen intézmények komoly létszáma azzal magyarázható, hogy azok egy bi- 


\section{TEMATIKUS TANULMÁNYOK - Kárpátalja társadalma}

zonyos része nem rendelkezik a hatályos jogszabály által előírt elegendő eszközzel, hogy teljes mértékben befejezze a felszámolási eljárást, másik része pedig bizonyos eszközökkel és hitelállománnyal rendelkezve, vagy öneladásából származó bevétel és hitel visszafizetéseket tud magáénak, amelyeket a betétesek között el lehet osztani (pl. „Central-Start” vagy „Mrija” hitelszövetkezet).

Jelenleg a szövetkezeti hitelintézetek piacán 15 hitelszövetkezet múködik, ami tízzel kevesebb, mint 2010-ben. Ez alatt az idő alatt az állami pénzügyi intézmények nyilvántartásából kizárásra került jó néhány hitelszövetkezet, többek között a „Mrija”, „Central-Start”, „,Turja”, „Inter-C”, „Zakarpattya” stb. A vizsgált időszak alatt drasztikusan, több, mint a felére csökkent a hitelszövetkezetek tagjainak száma: 120,1 ezer főről (2010-ben) 59,6 ezer főre (2015-ben). Megjegyzendő, hogy 2011 végén csak a „Mrija” hitelszövetkezetnek 52,3 ezer tagja volt. Így Kárpátalja legnagyobb hitelszövetkezetéhez kapcsolódik a térségben a szövetkezeti hitelrendszerből kilépett tagok számának 86,5\%-a.

A vizsgált időszakban ugyancsak jelentősen csökkent a hitelszövetkezeti hitelfelvevők száma, mégpedig 82,7\%-ra, ami a 2010-es 33,9 ezer fővel szemben 2015-ben már csak 5,9 ezer fót jelentett. A hitelszövetkezeti tagok hitelaktivitásának visszaesésére utal a hitelfelvevők arányának csökkenése a teljes taglétszámban 28,2\%-ról (2010-ben) 9,9\%-ra (2015-ben). Ez az érték egyértelműen csökkenő tendenciát mutat. (4. táblázat)

A szövetkezeti hitelintézeti szegmens beszűkülésének ellenére a régióban a vizsgált időszak alatt nőtt a hozzájárulással rendelkező hitelszövetkezeti tagok aránya, így ez a mutató a 2010-es 4,3\%-hoz képest 2015-ben 6,2\%-ra növekedett. Ugyancsak szükséges megjegyezni, hogy a hitelszövetkezeti tagok számának csökkenése összefügg azzal az általános tendenciával is, mely szerint kizárásra kerülnek azok a résztulajdonosok, akik hosszabb időn keresztül nem veszik igénybe a szövetkezet szolgáltatásait. Az inaktív tagok további pénzügyi és adminisztratív terhet jelentenek a hitelszövetkezet számára a vezetési feladatok ellátása során, mivel a befektetők hiányzása nem mindig teszi lehetővé a közgyűlés megtartását, valamint növeli a müködési költségeket is.

A szövetkezeti hitelintézeti szegmensben kialakult kedvezőtlen helyzet negatívan hatott a befizetett hozzájárulások (65,3\%), tőke (9,7\%), eszközök $(87,9 \%)$ öszszegére, illetve a tagoknak kiadott hitelek $(86,4 \%)$ összegére (a zárójelben látható mutatók a tényezők csökkenését jelzik az előző év százalékában kifejezve). A tőke aránya a hitelszövetkezeti eszközökben csak 2011-ben csökkent és a továbbiakban egyértelmű növekedési tendenciát mutatott, ami a hitelszövetkezeti pénzügyi függetlenség erősödéséről tanúskodik. 2015-ben ez a mutató 42,1\% volt.

A vizsgált időszak alatt a régióban a hitelszövetkezetek fogyatkozása volt tapasztalható. Így 2015-ben egy átlag kárpátaljai hitelszövetkezet 4,1 milliós aktívával rendelkezett, ami 31,4\%-kal marad el a 2010-es évi mutatótól, jóllehet a 2009-2010. évi drasztikus esés után az utóbbi három év növekedést mutatott. Ez jellemzi a tagok 
www. metszetek.unideb.hu

\section{TEMATIKUS TANULMÁNYOK - Kárpátalja társadalma}

átlagszámát is: 2010-ben egy átlag kárpátaljai hitelszövetkezet 4,8 ezer főt tudhatott magáénak, míg 2015-ben már csak 3,98 ezret.

4. táblázat. A kárpátaljai szövetkezeti hitelintézetek fejlődésének általános mutatói 2010-2015 között

\begin{tabular}{|l|c|c|c|c|c|c|c|c|}
\hline \multirow{2}{*}{ Mutató } & \multicolumn{5}{|c}{ Mutató értéke éves felbontásban } & \multicolumn{3}{c|}{ Változás } \\
\cline { 2 - 9 } & 2010 & 2011 & 2012 & 2013 & 2014 & 2015 & Absz. & $\%$ \\
\hline $\begin{array}{l}\text { Hitelszövetkezetek száma } \\
\text { Kárpátalján, db }\end{array}$ & 25 & 22 & 19 & 17 & 17 & 15 & -10 & $-40,0$ \\
\hline Teljes taglétszám, fó & 120114 & 112755 & 56514 & 56984 & 59052 & 59654 & -60460 & $-50,3$ \\
\hline $\begin{array}{l}\text { Hozzájárulással rendelkező } \\
\text { tagok száma, fő }\end{array}$ & 5214 & 4035 & 2317 & 2255 & 2401 & 3727 & -1487 & $-28,5$ \\
\hline Hitelfelvevő tagok száma, fő & 33909 & 26704 & 10179 & 9439 & 9083 & 5882 & -28027 & $-82,7$ \\
\hline $\begin{array}{l}\text { Kárpátaljai hitelszövetkezetek- } \\
\text { nél hozzájárulással rendelkező } \\
\text { tagok aránya, \% }\end{array}$ & 4,3 & 3,6 & 4,1 & 4,0 & 4,1 & 6,2 & 1,9 & - \\
\hline $\begin{array}{l}\text { Kárpátaljai hitelszövetkezetek- } \\
\text { nél hitelfelvevő tagok aránya, } \\
\text { \% }\end{array}$ & 28,2 & 23,7 & 18,0 & 16,6 & 15,5 & 9,9 & $-18,4$ & - \\
\hline $\begin{array}{l}\text { Tagoknak kiadott hitel, } \\
\text { millió UAH }\end{array}$ & 144,6 & 126,6 & 62,7 & 61,7 & 64,7 & 58,2 & $-86,4$ & $-59,8$ \\
\hline $\begin{array}{l}\text { Hozzájárulás (befektetés), } \\
\text { millió UAH }\end{array}$ & 96,5 & 75,6 & 44,5 & 38,2 & 39,3 & 31,2 & $-65,3$ & $-67,7$ \\
\hline $\begin{array}{l}\text { Hitelszövetkezeti tőke, } \\
\text { millió UAH }\end{array}$ & 35,5 & 37,1 & 16,4 & 20,3 & 23,3 & 25,9 & $-9,7$ & $-27,2$ \\
\hline Eszközök, millió UAH & 149,4 & 126,3 & 69,4 & 64,0 & 66,8 & 61,5 & $-87,9$ & $-58,9$ \\
\hline $\begin{array}{l}\text { Tőke aránya az összes } \\
\text { eszközben, \% }\end{array}$ & 23,8 & 29,3 & 23,6 & 31,7 & 34,8 & 42,1 & 18,3 & - \\
\hline $\begin{array}{l}\text { A hitelfelvevő és } \\
\text { betételhelyező tagok arányai }\end{array}$ & 6,50 & 6,62 & 4,39 & 4,19 & 3,78 & 1,58 & $-4,93$ & $-75,7$ \\
\hline $\begin{array}{l}\text { Hitelszövetkezeti eszközök } \\
\text { átlagértéke, millió UAH }\end{array}$ & 5,98 & 5,74 & 3,65 & 3,76 & 3,93 & 4,10 & $-1,88$ & $-31,4$ \\
\hline $\begin{array}{l}\text { Hitelszövetkezeti tagok } \\
\text { átlagszáma, ezer fő }\end{array}$ & 4,80 & 5,13 & 2,97 & 3,35 & 3,47 & 3,98 & $-0,83$ & $-17,2$ \\
\hline
\end{tabular}

Forrás: Az Ukrajnai Pénzügyi Szervezetek Nemzeti Bizottságának adatai: www.nfp.gov.ua

Annak ellenére, hogy abszolút értékek tekintetében a kárpátaljai szövetkezeti hitelintézetek a nemzeti hitelszövetkezeti piac elenyésző részét teszik ki, működésük relatív mutatóinak összehasonlító elemzése alapján megyei, illetve ukrajnai vonatkozásban is alaposabb értékelést lehet végezni, valamint következtetésekre jutni. Az 5. számú táblázatban kiválasztottuk, valamint kiszámoltuk azon mutatókat, melyek összehasonlító elemzésre adnak lehetőséget, valamint amelyek alapján össze tudjuk vetni a regionális és nemzeti szövetkezeti hitelintézetek múködését. 
www. metszetek.unideb.hu

\section{TEMATIKUS TANULMÁNYOK - Kárpátalja társadalma}

5. táblázat. A szövetkezeti hitelintézetek működési mutatói kárpátaljai és ukrajnai viszonylatban 2010-2015 között

\begin{tabular}{|c|c|c|c|c|c|c|c|c|c|c|c|c|c|c|}
\hline \multirow[b]{3}{*}{ Mutató } & \multicolumn{12}{|c|}{ Mutató értéke éves felbontásban } & \multirow{2}{*}{\multicolumn{2}{|c|}{$\begin{array}{c}\text { Változás } \\
\text { 2015/2010 }\end{array}$}} \\
\hline & \multicolumn{2}{|c|}{2010} & \multicolumn{2}{|c|}{2011} & \multicolumn{2}{|c|}{2012} & \multicolumn{2}{|c|}{2013} & \multicolumn{2}{|c|}{2014} & \multicolumn{2}{|c|}{2015} & & \\
\hline & $\begin{array}{l}\frac{\pi}{\pi} \\
\frac{\pi}{5} \\
\frac{\pi}{5}\end{array}$ & 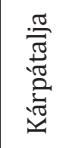 & $\frac{\sqrt[\pi]{\Xi}}{\sqrt[\pi]{\frac{\pi}{\sigma}}}$ & 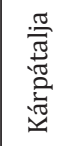 & $\frac{\sqrt[\pi]{a}}{\frac{\pi}{\pi}}$ & 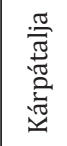 & $\begin{array}{l}\stackrel{\pi}{\pi} \\
\stackrel{\pi}{\frac{\pi}{y}} \\
\vdots\end{array}$ & 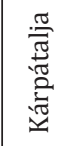 & 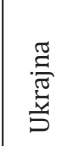 & 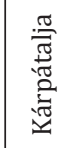 & 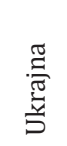 & 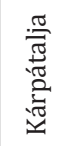 & $\frac{\pi}{\stackrel{\pi}{\pi}}$ & 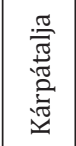 \\
\hline $\begin{array}{l}\text { A hitelszövetke- } \\
\text { zetek eszközeinek } \\
\text { GDP-ben(GRP) } \\
\text { való részesedé- } \\
\text { se, } \%\end{array}$ & 0,46 & 1,19 & 0,32 & 0,83 & 0,18 & 0,38 & 0,18 & 0,30 & 0,17 & 0,31 & 0,15 & 0,27 & $-0,31$ & $-0,92$ \\
\hline $\begin{array}{l}\text { Tőke aránya a hi- } \\
\text { telszövetkezetek } \\
\text { eszközeiben, \% }\end{array}$ & 18,2 & 23,8 & 32,6 & 29,3 & 39,5 & 23,6 & 41,0 & 31,7 & 40,6 & 34,8 & 44,8 & 42,1 & 26,7 & 18,3 \\
\hline $\begin{array}{l}\text { Betéttel rendelke- } \\
\text { ző tagok aránya, } \\
\%\end{array}$ & 5,34 & 4,34 & 5,02 & 3,58 & 4,52 & 4,10 & 4,10 & 3,96 & 4,11 & 4,07 & 3,83 & 6,25 & $-1,51$ & 1,91 \\
\hline $\begin{array}{l}\text { Hitellel rendelke- } \\
\text { ző tagok aránya, } \\
\%\end{array}$ & 19,3 & 28,2 & 21,8 & 23,7 & 23,5 & 18,0 & 23,2 & 16,6 & 23,8 & 15,4 & 22,7 & 9,9 & 3,4 & $-18,4$ \\
\hline $\begin{array}{l}\text { Hitelfelvevők be- } \\
\text { tétesekhez mért } \\
\text { aránya,fő }\end{array}$ & 3,62 & 6,50 & 4,35 & 6,62 & 5,19 & 4,39 & 5,66 & 4,19 & 5,80 & 3,78 & 5,92 & 1,58 & 2,30 & $-4,93$ \\
\hline $\begin{array}{l}\text { A hitelszövetke- } \\
\text { zetekbe bevont } \\
\text { lakosság aránya, } \\
\%\end{array}$ & 4,78 & 9,65 & 3,44 & 9,04 & 2,34 & 4,52 & 2,41 & 4,54 & 2,16 & 4,70 & 1,91 & 4,74 & $-2,87$ & $-4,91$ \\
\hline $\begin{array}{l}\text { Betéttel rendel- } \\
\text { kező lakosság } \\
\text { aránya, \% }\end{array}$ & 0,26 & 0,42 & 0,17 & 0,32 & 0,11 & 0,19 & 0,10 & 0,18 & 0,09 & 0,19 & 0,07 & 0,30 & $-0,18$ & $-0,12$ \\
\hline $\begin{array}{l}\text { Hitelt felvett la- } \\
\text { kosság aránya, \% }\end{array}$ & 0,93 & 2,72 & 0,75 & 2,14 & 0,55 & 0,81 & 0,56 & 0,75 & 0,51 & 0,72 & 0,43 & 0,47 & $-0,49$ & $-2,26$ \\
\hline $\begin{array}{l}\text { Az eszközök } \\
\text { átlagértéke, millió } \\
\text { hrivnya }\end{array}$ & 5,59 & 5,98 & 5,21 & 5,74 & 3,89 & 3,65 & 4,31 & 3,76 & 4,16 & 3,93 & 3,97 & 4,10 & $-1,62$ & $-1,88$ \\
\hline $\begin{array}{l}\text { Hitelszövetkezeti } \\
\text { tagok átlag létszá- } \\
\text { ma, ezer fő }\end{array}$ & 2,90 & 4,80 & 2,38 & 5,13 & 1,73 & 2,97 & 1,78 & 3,35 & 1,57 & 3,47 & 1,39 & 3,98 & $-1,51$ & $-0,83$ \\
\hline $\begin{array}{l}\text { Hitelszövetkezeti } \\
\text { tag átlagtartozása, } \\
\text { ezer hrivnya }\end{array}$ & 9,2 & 4,3 & 9,8 & 4,7 & 9,0 & 6,2 & 10,0 & 6,5 & 10,1 & 7,1 & 10,7 & 9,9 & 1,5 & 5,6 \\
\hline $\begin{array}{l}\text { Hitelszövetkezet } \\
\text { tagjával szembeni } \\
\text { átlagtartozása, } \\
\text { ezer hrivnya }\end{array}$ & 25,3 & 18,5 & 24,7 & 18,7 & 24,7 & 19,2 & 28,7 & 16,9 & 33,0 & 16,4 & 31,4 & 8,4 & 6,1 & $-10,1$ \\
\hline
\end{tabular}

Forrás: Saját számítás 


\section{TEMATIKUS TANULMÁNYOK - Kárpátalja társadalma}

Egyes esetekben - a vizsgált időszakban - a hitelszövetkezeti eszközök részarányának csökkenése volt tapasztalható a gazdaságban mind regionális, mind állami szinten. Ugyanakkor az a tendencia látható, hogy a kárpátaljai hitelszövetkezetek eszközeinek súlya dominál az ukrajnai összmutató vonatkozásában. Így, 2010-ben a kárpátaljai hitelszövetkezetek eszközei a kárpátaljai GRP 1,19\%-át tették ki, miközben az országos mutató csupán 0,46\% volt, 2015-ben pedig ez az érték 0,27\%, illetve 0,15\%-os szintet ért el. Tehát a hitelszövetkezetek pénzügyi forrásainak súlya a régió gazdaságában jelentősen magasabb, mint Ukrajnában.

A statisztikai adatok arra engednek következtetni, hogy a válság után a hitelszövetkezeti tagok aránya Kárpátalján meghaladja az analóg ukrajnai mutatót és arról tanúskodik, hogy a régió azon lakosságának megtakarításai növekednek, akik hitelszövetkezeti tagok. Ennek értelmében a kárpátaljai betétesek aránya 4,3\%-ról (2010) 6,5\%-ra nőtt (2015), országos szinten pedig ugyanebben az időszakban aránycsökkenés volt tapasztalható, mégpedig 5,3\%-ról 3,8\%-ra. Tehát a válság utáni időszakban a hitelszövetkezeti betétesek aránya Kárpátalján 2,2\%-al növekedett, miközben Ukrajnában 1,5\%-kal csökkent.

Míg országos szinten a hitelfelvevők betételhelyezőkhöz viszonyított aránya az utóbbi öt évben 2,3-mal nőtt, addig a regionális mutató 4,93-mal csökkent. Ebből kifolyólag Ukrajnában 2015-ben egy betétesre 5,92 hitelfelvevő jut, eközben Kárpátalján csak 1,58. Ennek a mutatónak a drasztikus növekedése a hitelszövetkezeti szférában várható jövőbeni problémákra utalhat, hisz a hitelintézetek fő forrását a tagok betétei képezik.

Szükséges megjegyezni, hogy a kedvezőtlen feltételek, melyek az ukrán szövetkezeti hitelintézeteknél jelentek meg, negatívan hatottak a szövetkezeti mozgalom elterjedésére a lakosság körében. Ha 2010-ben Ukrajna lakosságának 4,8\%-a, Kárpátalján pedig 9,7\%-a vállalt hitelszövetkezeti tagságot, addig 2015-ben ezek az értékek 1,9\%, illetve 4,7\%-ra csökkentek. Megjegyzendő, hogy Kárpátalján a hitelszövetkezeti mozgalomba bevont lakosság száma különböző vizsgált évek tekintetében átlagosan több, mint kétszeresen haladta meg az országos érteket. Ezek az adatok újra alátámasztják a régióban élő lakosság hajlandóságát arra, hogy kifejezetten ezt a szegmenset használják a pénzügyi jellegű szükségleteik kielégítésére.

A hitelfelvevők átlagos tartozásának mutatói Ukrajnában és Kárpátalján arra engednek következtetni, hogy Kárpátalján a hitelszövetkezetek egy megfontoltabb és körültekintőbb hitelezési politikát folytatnak, hiszen 2015-ben az átlag ukrajnai mutató 10,7 ezer hrivnyát, míg a megyei 9,9 ezer hrivnyát tett ki. Egyúttal a vizsgált időszakban komoly emelkedés volt tapasztalható a hitelszövetkezeti tagokra eső átlagtartozás összegében, mégpedig 4,3 ezer hrivnyáról 9,9 ezerre, miközben az országos érték csak 1,5 ezer hrivnyával változott növekedés irányába. 
www. metszetek.unideb.hu

\section{TEMATIKUS TANULMÁNYOK - Kárpátalja társadalma}

A kárpátaljai hitelszövetkezetek lényeges jellemzője a betétgyűjtési és hitelezési tevékenység. A 6. számú táblázatban a kárpátaljai szövetkezeti hitelintézetek hitelés betétállományának struktúráját láthatjuk.

6. táblázat. A kárpátaljai hitelszövetkezetek hitel- és betétállomány struktúrája 2013-2015 között futamidős felbontásban (\%)

\begin{tabular}{|c|c|c|c|c|c|c|c|c|c|c|c|}
\hline \multirow{3}{*}{ Év } & \multicolumn{10}{|c|}{ A hitelszövetkezeti hitelek és betétek struktúrája futamidő függvényében, \% } & \multirow{3}{*}{$\begin{array}{l}\text { hitel/ } \\
\text { betét } \\
\text { arány }\end{array}$} \\
\hline & \multicolumn{2}{|c|}{ <3 hónap } & \multicolumn{2}{|c|}{ 3-12 hónap } & \multicolumn{2}{|c|}{ >12 hónap } & \multicolumn{2}{|c|}{$\begin{array}{c}\text { Látra szóló } \\
\text { betétek }\end{array}$} & \multicolumn{2}{|c|}{ Összesen } & \\
\hline & Hitel & Betét & Hitel & Betét & Hitel & Betét & Hitel & Betét & Hitel & Betét & \\
\hline 2013 & 1,15 & 0,87 & 24,44 & 19,75 & 74,41 & 72,74 & - & 6,64 & 100,0 & 100,0 & 1,62 \\
\hline 2014 & 0,91 & 0,80 & 25,67 & 18,76 & 73,42 & 78,89 & - & 1,55 & 100,0 & 100,0 & 1,65 \\
\hline 2015 & 0,21 & 2,04 & 26,37 & 18,07 & 73,42 & 77,24 & - & 2,65 & 100,0 & 100,0 & 1,87 \\
\hline $\begin{array}{l}\text { Változás } \\
\text { 2013/2015 }\end{array}$ & $-0,94$ & 1,17 & 1,93 & $-1,68$ & $-0,99$ & 4,50 & - & $-3,99$ & - & - & 0,15 \\
\hline
\end{tabular}

Forrás: Saját számítás

A fenti adatokból megállapítható a nem banki hitelintézetek hitel- és betétállományának csökkenése, még hozzá a betétek visszaesése lényegesebb, és közel felére múlja felül a hitelezés fogyatkozását. 2013-2015 között a betétállomány 7 millió hrivnyával szúkült, a hitelállomány viszont 3,5 millió hrivnyával. Általánosságban elmondható, hogy a kárpátaljai hitelszövetkezetek elérték a hitelek és betétek futamideje közötti egyensúlyt, hisz 2014-től kezdve a hosszú távra lekötött betétek aránya lényegesen meghaladja a hosszú lejáratú hitelekét, 2015-ben 77,24\%-ot, illetve 73,42\%-ot tett ki. A rövid lejáratú hiteleket pedig a rövidtávú betétekkel finanszírozzák.

Ugyanakkor megfigyelhető az a negatív tendencia, mely szerint növekszik a hitelek aránya a begyűjtött betétekhez képest, így 2013-ben ez az érték 1,62\%-ot tett ki, míg 2015-ben 1,87\%-ot. Az adatok alapján arra lehet következtetni, hogy a kárpátaljai hitelszövetkezetek által kiadott hitelek csupán fele fedeződik díjbevételi forrásokból és előnyös módját képezi az elemzett hitelintézetek működésének finanszírozására.

A kárpátaljai hitelszövetkezetek működéselemzésénél fontos kérdést képez azok betételhelyezési tevékenysége. Ez utóbbi a hitelforrások fő alapja. A vizsgált időszakban a legjelentősebben a „Szvjatij Martin” hitelszövetkezet betétállománya növekedett, mégpedig 3,25 millió hrivnyával, illetve 2015-ben erre az intézetre esett a regionális szövetkezeti hitelintézetek betétjeinek 47,3\%-a. A betétállomány nagyságának tekintetében a második helyen a megyében a „Beszkid” hitelszövetkezet áll, melynek összege 2015-ben 9,01 millió hrivnyát tett ki, a piaci részesedése pedig több mint $26 \%$ volt. A harmadik legtöbb betéttel rendelkező hitelszövetkezet a „Ho- 


\section{TEMATIKUS TANULMÁNYOK - Kárpátalja társadalma}

Szen", amely tagjainak hozzájárulásai 2013-2015 között a harmadára csökkentek, a piaci részesedése pedig 8,8\%-ról (2013) 7,5\%-ra (2015) fogyatkozott.

Általában véve a Kárpátalján működő hitelszövetkezetek inkább a hosszú távú hitelezést részesítik előnyben, így 2013-2015 között a hitelállomány körülbelül 74\%-át az egy évet meghaladó lejáratú hitelek tették ki, több mint negyedét a 3-tól 12 hónapig terjedő időtartamú hitelek képezték és csak kis hányadát (körülbelül 0,5\%) adták ki 3 hónapon belüli futamidőre.

Megjegyzendő, hogy a jövedelmek visszaesésénél a lakosság aktívabban fordul a pénzintézetekhez hitelért és ismeretes, hogy a kereskedelmi bankokhoz képest a hitelszövetkezeteknél sokkal egyszerúbben lehet hitelhez jutni. Azonban ez az egyszerűsített eljárás sok esetben vezet fizetési késedelemhez, vagy a visszatérítés elmaradáshoz.

Értelemszerűen a kárpátaljai hitelszövetkezeti piacvezetők, illetve az outsiderek meghatározására 2013-2015-re vonatkozóan el kell végezni a piaci résztvevők mutatóinak PEARLS pénzügyi monitoring rendszer szerinti értékelését.

A kárpátaljai szövetkezeti hitelintézetek általi PEARLS ${ }^{7}$ mutatóknak (www.woccu.org) való megfelelőség értékelésénél tekintettel kell lenni arra, hogy a regionális hitelszövetkezetek múködésére vonatkozó előző évi megbízható adatok hiánya végett 2013-ban csak 17 mutató, 2014-2015-ben pedig 34 mutató vonatkozásában kerültek kiszámításra ezek az adatok. A 41 lehetséges mutatóból 34-nek a kiszámítása annak tudható, hogy az értékelést csak a pénzügyi beszámoló bizonyos mezőinek, adatainak meglétekor lehet elvégezni. A PEARLS kritériumok vonatkozásában a legmagasabb 100\%-os teljesítményt minden vizsgált év tekintetében azok a mutatók érték el, amelyek a nem termelő eszközök, valamint rövid távú pénzügyi befektetések minimalizálásáról tanúskodik a hitelszövetkezetek eszközeiben. Ugyancsak magas szintű megfelelés tapasztalható a külső források bevonásának optimális arányának megtartása tekintetében, ami a hitelintézet konzervatív pénzgazdálkodási politikájáról tesz tanúságot.

A kárpátaljai hitelszövetkezetek számára legnehezebben megy a likviditási mutatók betartása, ami a minőségi hitelállomány formális irányításának hiányosságaira, valamint a nem megfelelő eszközgazdálkodásra utal azok magas jövedelmezőségszintjének elérése tekintetében.

A hitelszövetkezetek pénzügyi tevékenységét elemezve kiemelkedően jó a hitelportfólió diverzifikálása, ami egyben a vissza nem fizetési kockázat csökkenését is jelenti. A kárpátaljai hitelszövetkezetek konzervatív hitelezési és betét-politikájának köszönhetik kimagasló eredményeiket a többi ukrajnai régióban tevékenykedőkhöz

${ }^{7}$ PERLS mutató feladata, hogy jelezni adott pénzintézmény biztonságosságának a fokát. A mutató egy mozaikszó, melynek jelentése: Protection - védelem; Effective Financial Structure - pénzügyi rendszer hatékonysága; Asset Quality - befektetési eszközök minőségbiztosítása; Rates of Return and Costs Visszafizetési és költség ráták; Liquidity - likviditás; Signs of Growth - növekedési indikátorok. 
www. metszetek.unideb.hu

\section{TEMATIKUS TANULMÁNYOK - Kárpátalja társadalma}

képest. Éppen ezért fontos lehet a jövőben egy hitelszövetkezet megjelenése a kárpátaljai magyarok által sûrún lakott járásokban - Beregszászban és a Beregszászi járásban -, ugyanis itt nincs bejegyezve és nem is müködik hitelszövetkezet.

\section{A Kárpátalján vállalkozásfejlesztésre irányuló magyarországi célirányos támogatások elemzése az Egán Ede-tervben megfogalmazott kitörési pontok fényében}

2013 novemberétől Ukrajnában egyre inkább begyűrűző válságállapot tapasztalható. Az ország keleti részén befagyott polgárháborús állapotok uralkodnak, a gazdaság tejesen összeomlott, azt csupán a nyugati és az IMF kölcsönök tartják mesterségesen egyben (Tálas 2015: 111).

A politikai és gazdasági bizonytalanság nem kedvez a Kárpátalján meglévő migrációs helyzetnek sem. Míg a múlt évtizedben Bárdi Nándor kutatásában megjegyzi, hogy az elszakított nemzetrész magyarlakta területei közül Kárpátalján a legalacsonyabb a kivándorlás (Bárdi 2004), addig napjainkban ez a tendencia teljesen megfordult. Ezt Tátrai - Erőss - Kovály (2016) tanulmánya is alátámassza, melyből látható, hogy 2011-2014 között „a hírek a kárpátaljaiak tömeges Magyarországra vándorlásáról, illetve munkavállalásáról számoltak be, egyrészt a katonai behívók elől, másrészt a kilátástalan gazdasági körülmények miatt." (Tátrai - Erőss - Kovály 2016). Az tény, hogy a kárpátaljai magyarok körében végzett reprezentatív társadalomkutatás is beszámol az itt élő magyarság erős nemzeti és lokális identitásáról, mivel a Kárpátalján élő magyar nem csupán magyarnak, hanem kárpátaljai magyarnak vallja magát. Az utóbbi négy év eseményei azonban az ukrajnai munkaképes lakosság jelentős hányadát külföldi munkavállalásra sarkallták. A Kárpátalján élő magyarság sem volt ez alól kivétel. Az elvándorlás katalizátora a helyi magyarok számára könynyen elérhető egyszerüsített honosítási eljárás által megszerezhető magyar állampolgárság, mely egyben EU-s állampolgárságot is jelent. Így a kilátástalan helyzetbe kerülő kárpátaljai lakosok nem csupán az anyaországban, hanem az Európai Unió bármely országában vállalhatnak munkát ${ }^{8}$.

A gazdasági kivándorlás a diplomával rendelkező, egészségügyi és tanári munkakörben dolgozókat, illetve a munkaképes korú férfiakat érinti a leginkább.

„Nekünk fontos, hogy a kárpátaljai magyarok a szülőföldjükön boldogulhassanak, éppen ezért a magyar kormány minden támogatást meg akar adni ehhez" - jelentette ki Balogh Zoltán, az emberi erőforrások minisztere."

\footnotetext{
${ }^{8}$ Migráció témakörében lásd még a Tandem 2016 - Kárpátaljai szociológiai felmérés c. tanulmányt (http://bgazrt.hu/npki/kutatasok/tandem_2016/)

${ }_{9}^{9}$ Balog Zoltán 2016. A Magyar Kormánynak fontos a kárpátaljai magyarok boldogulása. http://www. hirado.hu/2016/09/18/balog-zoltan-a-magyar-kormanynak-fontos-a-karpataljai-magyarok-boldogulasa/
} 


\section{TEMATIKUS TANULMÁNYOK - Kárpátalja társadalma}

A rossz ukrajnai gazdasági helyzet arra kényszeríti a fiatal munkaképes lakosságot, hogy az országon kívül keressen jobb megélhetési lehetőséget. Nem kivétel ez alól a kárpátaljai magyarság sem, melynek elvándorlása már Ukrajna 1991 kikiáltása óta folyamatosan növekszik. Magyarország kormánya látva ezt az egyre kritikusabbá váló helyzetet, speciális, csak Kárpátaljára vonatkozó támogatási kategóriákat nyitott meg, a közszférában dolgozók és a helyi gazdasági szféra fellendítésére.

A magyarok helyben maradásának egyik legfőbb lehetősége az, ha önálló gazdasági tevékenységet tudnak folytatni önmaguk, ill. családjuk egzisztenciáját biztosítva. Ennek érdekében a Kárpátaljai Magyar Kulturális Szövetség megbízásából kidolgozásra került „A kárpátaljai magyarság gazdaságfejlesztési stratégiai terve” (Egán Ede-terv 2014) ${ }^{10}$. Ez a terv szorosan összekapcsolódik a Wekerle-tervhez (NGM) és annak alap stratégiai elgondolásához, mely szerint a Magyar Kormány csak egységes kárpát-medencei gazdaságfejlesztést tart elfogadhatónak: „A magyar kormány kárpát-medencei szintű célkitüzéseinek megvalósítása során stratégiai szövetségesként tekint a szomszédos országokban élö magyar nemzeti közösségekre, a szomszédos országokkal való kapcsolat szorosabbra füzésében épít a magyar közösségek helyismeretére, tapasztalataira, a nyelvi akadályok leküzdésében nyújtott segítségére. Magyarország célja, hogy a gazdasági feltételek javítása révén is hozzájáruljon határon túli magyarság szülőföldön való megmaradásához"11.

Ennek kapcsán a Magyar Kormány több támogatási programon keresztül próbálja ösztönözni a kárpátaljai magyarokat egzisztenciájuk létrehozására. Ezt segíti elő a Magyar Kormány Nemzetpolitikai államtitkárságának 2016-tól elindított programja, melyet a Bethlen Gábor Alapkezelő Zrt. (BGA) a Kárpát-medencében élő fiatal vállalkozók számára tett elérhetővé. A fiatal vállalkozók évének meghirdetésével összhangban pályázatot írtak ki 40 év alatti kárpát-medencei vállalkozók támogatására. A pályázat keretei között 600 millió HUF vissza nem térítendő támogatás került kiosztásra. Összesen 967 támogatási kérelmet nyújtottak be, ezek közül 117 nyert. Kárpátaljáról 15 vállalkozó részesült támogatásban a benyújtott 139 pályázatból (1. ábra). A támogatási rendszer kidolgozásával párhuzamosan a Hétfa Kutatóintézet vizsgálta a támogatási célterület társadalmi-gazdasági és vállalkozói környezetét, melyet a Megkapaszkodás, gyarapodás, bátorítás (2016) c. tanulmányban fejt ki régiónkénti összehasonlításban, önállóan kezelve egy-egy térséget.

\footnotetext{
${ }^{10}$ Egán Ede Gazdaságfejlesztési Terv 2014: 65. https://www.eganede.com/egan-ede-terv.pdf.

${ }^{11}$ Wekerle-terv. http://www.kkvhaz.hu/cikk/338-wekerle-terv
} 
www. metszetek.unideb.hu

\section{TEMATIKUS TANULMÁNYOK - Kárpátalja társadalma}

2. ábra. A kárpátaljai nyertes pályázatok részaránya

a BGA fiatal vállalkozói pályázatában 2016-ban (Ft)

$74072997,00 \mathrm{Ft}$

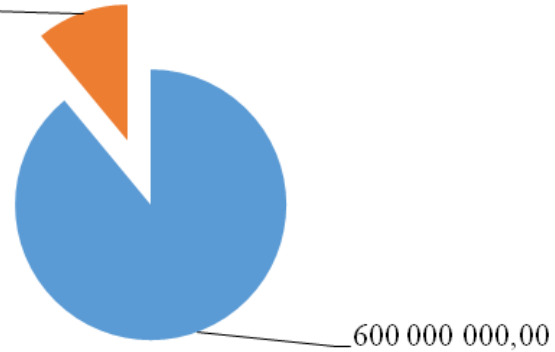

$\mathrm{Ft}$

Összes támogatás $\quad$ Kárpátalja

Forrás: BGA Zrt.

A Nemzetpolitikai Államtitkárság 2017-ben folytatta a programot, viszont a súlypont ebben az évben a családi vállalkozásokra helyeződött át. A for profit alapú pályázóknak ezúttal három kategóriában írták ki a pályázatokat a 7. táblázatnak megfelelően:

7. táblázat. 2017 a családi vállalkozások éve kapcsán meghirdetésre kerülő vállalkozói pályázatok $(\mathrm{Ft})$

\begin{tabular}{|l|c|c|}
\hline \multicolumn{1}{|c|}{ Kategória } & Pályázható keretösszeg & Teljes keretösszeg \\
\hline $\begin{array}{l}\text { Induló külhoni magyar fiatal } \\
\text { vállalkozások }\end{array}$ & $2000000 \mathrm{Ft}-3000000 \mathrm{Ft}$ & $120000000 \mathrm{Ft}$ \\
\hline Családi vállalkozások & $4000000 \mathrm{Ft}-6000000 \mathrm{Ft}$ & $600000000 \mathrm{Ft}$ \\
\hline $\begin{array}{l}\text { Fiatal vállalkozások } \\
\text { együttmüködése }\end{array}$ & $4000000 \mathrm{Ft}-4500000 \mathrm{Ft}$ & $110000000 \mathrm{Ft}$ \\
\hline Összesen & - & $830000000 \mathrm{Ft}$ \\
\hline
\end{tabular}

Forrás: BGA Zrt.

Látható, hogy idén domináns a családi vállalkozások kategóriája (72\%). Minden régióban más és más a családi vállalkozások jogi definiálása. Ukrajnában a célcsoport lefedésére szolgáló vállalkozási forma nincs, illetve az a sajátosság alakult ki, hogy ha kvázi családi vállalkozásként is múködnek, a jogi bejegyzés több egyéni vállalkozás között van megosztva, ami a családtagok nevére egyenként van bejegyezve. 


\section{TEMATIKUS TANULMÁNYOK - Kárpátalja társadalma}

Ez a jogi kiskapu lehetőséget biztosít a legkedvezőbb adófeltételek kihasználásra, amivel rendszerint élnek is a vállalkozók.

A másik - pénzbeli támogatottságát nézve jóval bőségesebb -, az Egán Ede program, mely az Egán Ede-terv konkrét megvalósítási formája. Az Egán Ede-terv célja a kárpátaljai magyarság megmaradása és fejlesztése az összmagyar fejlesztési koncepcióval összhangban, amely hosszútávú elgondolásnak megfelelően tud forrást tud biztosítani a kiemelt ágazatok számára. A tervben megfogalmazott prioritást élvező irányok a következők: mezőgazdaság-, vállalkozás- és turizmusfejlesztés.

Jövőképének 6 fő stratégiai pillére a következő:

1. A kárpátaljai magyarság gazdasági közösségének megteremtése;

2. Az emberi erőforrásaink megtartása, minőségük javítása;

3. A magyarlakta térség gazdasági versenyképességének növelése;

4. Széleskörű integrálódás a Kárpát-medencei gazdasági térbe;

5. Híd-szerep kialakítása az anyaországi gazdasági szereplők és az ukrán vállalkozói, fogyasztói szféra között;

6. A magyarlakta vidék termőföldjeinek helyben lakó gazdálkodók kezében tartása (Egán Ede Terv 2014: 27).

A terv Kárpátalja magyarlakta vidékeinek fejlesztésére vonatkozik és elsősorban a magyarság helyzetének javítására irányul. A fejlesztési program záró dátuma 2020. Ez egybecseng „Kárpát-Haza 2020” stratégiai terv megvalósítási idejével, hisz az Egán Ede-terv szerves részét képezi a stratégiai tervnek.

A program kivitelezésére létrejött az Egán Ede irodahálózat, amely ungvári központtal az ungvári, a beregszászi, a nagyszőlősi és a Felső-Tisza vidékét képviselő técsői regionális irodákat foglalja magába. ${ }^{12}$

Ennek megfelelően 2016-ban a Magyar Kormány 2 milliárd forintot különített el erre a célra. A támogatásokat az Egán Ede Jótékonysági Alapítványon keresztül bonyolítják le. A 2016-ban meghirdetett pályázatok a következő főbb kategóriákban (némelyeket alkategóriákra bontottak le) voltak elosztva:

Egyéni vállalkozók, valamint mikro- és kisvállalkozások kapacitásbővítési, innovációs támogatására a turisztika területén (keretösszege - 300 M Ft.)

1. A. Turisztikai vállalkozások eszközbeszerzésének támogatása (egy pályázónak adható maximális összeg - 2 M Ft).

1. B. Turisztikai beruházások támogatása (egy pályázónak adható maximális öszszeg - 4,5 M Ft).

Vállalkozások kapacitásbővítési, innovációs eszköztámogatása (keretösszege 500 M Ft, egy pályázónak adható maximális összeg - 4,5 M Ft).

Egyéni vállalkozók, valamint mikro- és kisvállalkozások kapacitásbővítési, innovációs támogatására a mezőgazdaság területén (keretösszege - 1100 M Ft).

\footnotetext{
${ }^{12}$ Egán Ede JA Kárpátaljai irodahálózata. https://www.eganede.com/irodak
} 


\section{TEMATIKUS TANULMÁNYOK - Kárpátalja társadalma}

3. A. Üveg- és fóliaházak telepítéséhez szükséges eszközök beszerzése (egy pályázónak adható maximális összeg - $2 \mathrm{M} \mathrm{Ft}$ ).

3. B. Kertészeti technológiai fejlesztéshez szükséges, valamint ültetvény-telepítési és talajjavítási eszközök beszerzése (egy pályázónak adható maximális összeg $-2 \mathrm{M} \mathrm{Ft}$ ).

3. C. Méhészet létrehozásához és fejlesztéséhez szükséges eszközök beszerzése (egy pályázónak adható maximális összeg - 0,5 M Ft).

3. D. Állattartó telepek fejlesztéséhez szükséges eszközök beszerzése (egy pályázónak adható maximális összeg - $3 \mathrm{M} \mathrm{Ft}$ ).

Mindemellett a magánszemélyek és vállalkozások számára kírásra került egy földprivatizációs pályázat, amely az Ukrajnában páj (пай) néven számon tartott szántóföldekre vonatkozik.

A 2016-os pályázati ciklusban a fejlesztési tervvel összehangolva turisztikai, mezőgazdasági és vállalkozás-fejlesztési célokra pályázhattak a kárpátaljai lakcímmel rendelkező, magyarságukat dokumentálisan igazolni tudó vállalkozók.

A pályázati kírás a megjelenést követően háromszor került pontosításra, az utolsó és egyben legmarkánsabb helyesbítésre a leadási határidőt megelőző héten került sor. Ennek lényege az volt, hogy már nem csak bejegyzett vállalkozók, hanem magánszemélyek is pályázhattak azzal a kikötéssel, hogy pályázatuk pozitív elbírálása esetén a támogatás folyósítását megelőzően vállalkozóként bejegyeztetik magukat.

A pályázók a három főkategórián belül eszközbeszerzésre pályázhattak, kivételt jelentett ez alól a turisztika kategória 1.A) alkategóriájában lévő infrastrukturális beruházási pályázat volt a kivétel, amelyet utólagos finanszírozással, a beruházás megléte után folyósítottak.

A pályázat maximális intenzitása a fejlesztés $80 \%$-át tehette ki, ami azt jelentette, hogy a beszerzés minimum $20 \%$ - át önerőből kell finanszírozni.

A 2 milliárd Ft-ból 100 millió Ft-ot a vállalkozások földtulajdoni dokumentumainak elkészítésének elősegítésére különítettek el. Ennek fényében megállapítható, hogy a mezőgazdasági, turizmus- és vállalatfejlesztésre Kárpátalján az Egán Ede program keretében 2016-ban 1,9 milliárd Ft-ot helyeztek el a célcsoportok között.

A pályázónak az www.eganede.com elektronikus felületen kellett regisztrálnia, majd csatolni a szükséges okmányokat (személyigazolvány, adóazonosító kód, magyarságot igazoló okirat, illetve árajánlat a megvásárolandó eszközökről és annak magyar nyelvű fordítása, amennyiben releváns tulajdonjogot / használati jogot igazoló dokumentumok, diploma és tanúsítvány másolatok, illetve valamely kárpátaljai szakmai szervezet ajánlata).

A pályázatokat 2016. augusztus 31-ig kellett benyújtani. A pályázatokkal kapcsolatos banki ügyintézést az ukrajnai OTP Bank-on keresztül végezték. Mivel a pályázók zöme nem értette volna meg a banki ügyletekben használt ukrán nyelvü dokumentációt, az OTP Bank felkérte a II. Rákóczi Ferenc Kárpátaljai Főiskolát, hogy 
www. metszetek.unideb.hu

\section{TEMATIKUS TANULMÁNYOK - Kárpátalja társadalma}

nyújtson neki segítséget a dokumentáció magyar nyelvre fordításában. Jelenleg minden egyes banki dokumentum, melyet az Egán Ede programban meghirdetett pályázóknál használnak, mind ukrán, mind magyar nyelven is hozzáférhető.

A pályázatok elbírálását egy helyszíni ellenőrzés előzte meg, amelyet a kompetens szakmai szervezet (Pro Agricultura Carpatica, KMVSZ ${ }^{13}$, Kárpátaljai Magyar Turisztikai Tanács) kijelölt tagjai hajtottak végre. A helyszíni jegyzőkönyvek elkészültét követően kezdetét vette a szakmai értékelés, amelyet az irodától teljesen független helyi és magyarországi gazdasági, turisztikai és mezőgazdasági területen jártas szakmai értékelő személyek végeztek. Az értékelés során egy megadott 100 pontos skálán kellett a pályázat részeit értékelni (mellékelt), a szükséges csatolmányokat ellenőrizni, valamint az árajánlat realitását megállapítani.

A pályázati határidő lezárásakor (2016.08.31) összesen 1190 pályázat érkezett be, ebből 1075 egyéni vállalkozó és 115 vállalkozás adott le pályázati anyagot (lást 8. sz. táblázat).

8. táblázat. A 2016-ban meghirdetett Egán Ede program keretében benyújtott pályázatok járási és kategóriák szerinti eloszlása $(\mathrm{db})$

\begin{tabular}{|c|c|c|c|c|c|c|c|c|}
\hline \multirow[b]{2}{*}{$\begin{array}{l}\text { Kategóriák } \\
\text { (alkategóriák)/ } \\
\text { Járások }\end{array}$} & \multicolumn{4}{|c|}{ Mezőgazdaság } & \multirow[b]{2}{*}{$\begin{array}{l}\text { Vállalkozás- } \\
\text { fejlesztés }\end{array}$} & \multicolumn{2}{|c|}{ Turisztika } & \multirow[b]{2}{*}{$\begin{array}{c}\text { Össze- } \\
\text { sen }\end{array}$} \\
\hline & $\begin{array}{c}\text { Üveg-és } \\
\text { fóliaházak }\end{array}$ & $\begin{array}{l}\text { Kertészeti } \\
\text { technológia }\end{array}$ & Méhészet & $\begin{array}{c}\text { Állattartó } \\
\text { telepek }\end{array}$ & & $\begin{array}{c}\text { Turisztika } \\
\text { eszköz- } \\
\text { beszerzés }\end{array}$ & $\begin{array}{l}\text { Turisztika } \\
\text { beruházás }\end{array}$ & \\
\hline $\begin{array}{l}\text { Ungvári } \\
\text { járás }\end{array}$ & 20 & 80 & 1 & 4 & 86 & 4 & - & 195 \\
\hline $\begin{array}{l}\text { Munkácsi } \\
\text { járás }\end{array}$ & 15 & 33 & 3 & 1 & 60 & 2 & 3 & 117 \\
\hline $\begin{array}{l}\text { Beregszászi } \\
\text { járás }\end{array}$ & 20 & 121 & 8 & 12 & 243 & 33 & 91 & 528 \\
\hline Huszti járás & - & 6 & - & 1 & 34 & 1 & 4 & 46 \\
\hline $\begin{array}{l}\text { Nagyszőlősi } \\
\text { járás }\end{array}$ & 47 & 100 & 3 & 21 & 81 & 6 & 17 & 275 \\
\hline Técsői járás & 2 & 2 & - & - & 17 & 1 & 2 & 24 \\
\hline Rahói járás & - & - & - & - & 4 & - & 1 & 5 \\
\hline $\begin{array}{l}\text { Összesen } \\
\text { alkateg. }\end{array}$ & 104 & 342 & 15 & 39 & 525 & 47 & 118 & 1190 \\
\hline $\begin{array}{l}\text { Összesen } \\
\text { fókateg. }\end{array}$ & \multicolumn{4}{|c|}{500} & 525 & \multicolumn{2}{|c|}{165} & 1190 \\
\hline
\end{tabular}

Forrás: Saját szerkesztés az Egán Ede Jótékonysági Alapítvány adatai alapán. https://www. eganede.com/palyazati-eredmenyek)

${ }^{13}$ KMVSZ- Kárpátaljai Magyar Vállalkozók Szövetsége. 


\section{TEMATIKUS TANULMÁNYOK - Kárpátalja társadalma}

A benyújtott pályázatok járás szerinti eloszlása nagyjából tükrözi a magyarság térbeli koncentrációját is: a legtöbb pályázatot a Beregszászi járásából nyújtották be - 528 pályázat, ami a programban részt vett pályázók 44,4\%-át tette ki. A Nagyszőlősi járásból 275 pályázat érkezett - ez a benyújtott pályázóknak a 23,1\%-a; a harmadik legtöbb pályázat Ungvárról és az Ungvári járásból érkezett - 195, ez a pályázók 16,4\%-át tette ki; Munkácsról és járásából 117 pályázatot adtak be és ez 9,8\%-a a programban résztvevőknek. A szórványvidékről (Rahói, Técsői és Huszti járásokból) összesen 75 pályázatot nyújtottak be - ez a beadott pályázatok csak 6,5\%-át jelenti.

Az 500 beérkező mezőgazdasági pályázat közül a legtöbben a Nagyszőlősi járásból pályáztak (37\%), a Beregszászi járásból a pályázatok 32,6\%-a érkezett, míg a 21\% az Ungvári járásból, a Munkácsi járás magyar falvaiból a pályázók 10,4\%-a származott.

A turisztikai pályázatok járások szerinti eloszlása homogenitást mutat, ugyanis a pályázók 76\%-a a Beregszászi járásból került ki. A vállalkozásfejlesztési pályázatoknál szintén Beregszász környéke dominált (49\%). De a többi magyarlakta térségben is arányosan kerültek beküldésre a pályázatok.

Település szerinti megoszlásban (5. sz. táblázat) a városok kiemelkedőek voltak (Beregszászból 46, Nagyszőlősről 34, Técsőről 20, Ungvárról 37, Viskről 45 pályázó adta be támogatási igényét).

9. táblázat. A támogatott pályázatok város és falu bontásban, fó és alkategóriánként (db)

\begin{tabular}{|l|c|c|}
\hline \multirow{2}{*}{ Kategória } & \multicolumn{2}{c|}{ Elhelyezkedés } \\
\cline { 2 - 3 } & Város & Falu \\
\hline Mezőgazdaság & 45 & 455 \\
\hline Vállalkozásfejlesztés & 212 & 313 \\
\hline Turisztika & 58 & 107 \\
\hline $\begin{array}{l}\text { Üveg- és fóliaházak telepítéséhez szükséges eszközök } \\
\text { beszerzése }\end{array}$ & 15 & 89 \\
\hline $\begin{array}{l}\text { Kertészeti technológiai fejlesztéshez szükséges, valamint } \\
\text { ültetvény-telepítési és talajjavítási eszközök beszerzése }\end{array}$ & 23 & 320 \\
\hline $\begin{array}{l}\text { Méhészet létrehozásához és fejlesztéséhez szükséges eszközök } \\
\text { beszerzése }\end{array}$ & 2 & 13 \\
\hline $\begin{array}{l}\text { Állattartó telepek fejlesztéséhez szükséges eszközök, beszer- } \\
\text { zése }\end{array}$ & 5 & 33 \\
\hline Vállalkozások kapacitásbővítési, innovációs eszköztámogatása & 212 & 313 \\
\hline Turisztikai vállalkozások eszközbeszerzésének támogatása & 11 & 36 \\
\hline Turisztikai beruházások támogatása & 47 & 71 \\
\hline Összes beadott pályázat szerint & 315 & 875 \\
\hline
\end{tabular}

Forrás: Egan Ede Jótékonysági Alapítvány adatai. www.eganede.com/palyazati-eredmenyek 


\section{TEMATIKUS TANULMÁNYOK - Kárpátalja társadalma}

A falvak közül kiemelkedő az Ungvári járásban található Nagydobrony 60 benyújtott pályázattal, a Nagyszőlősi járásból Tiszapéterfalva 34, és Feketepatak 20 pályázattal. Beregszászi járásból a legtöbb pályázat Nagybégányból érkezett be, számszerint 25 darab. Meg kell továbbá említeni Beregdédát és Nagybereget 23-23 benyújtott érvényes pályázattal, Mezőgecséből 22 pályázatot nyújtottak be. A Munkácsi járásból Dercen emelkedett ki 23 pályázattal.

A pályázók bejegyzett lakcíme alapján elmondható, hogy a pályázók többsége falusi lakos, ez érthető, mivel a kárpátaljai magyarság körében túlnyomó többségben van a vidéki lakosság részaránya (63\%). Értelemszerűen a mezőgazdaság kategóriát a falusi lakcímmel rendelkezők választották inkább, de néhány pályázó a városi lakók közül is kikerült. Vállalkozási kategóriában a városi lakosok száma az előző arányához képest elég magas, míg a turisztikai fejlesztési lehetőséget igénybevevők hányada a területi eloszlással arányos.

A legmagasabb összegre a turisztikai beruházás kapcsán pályázhattak (4 500000 HUF), így nem meglepő, hogy ebben a kategóriában a legmagasabb a megpályázott összegek átlaga. A mezőgazdaságban a legtöbben földmegmunkáló eszközre és fóliasátorra pályáztak, ahol a max. összeg 2000000 HUF volt, ezt az átlagösszeg tükrözi.

A pályázók között a vállalkozások szerinti forma alapján megállapítható, hogy 90\% egyéni vállalkozó fizikai személynek minősülő vállalkozás. Csupán 10\% minősül vállalkozásnak, amely jogi személyiséggel rendelkezik. A vállalkozások részaránya a mezőgazdasági kategóriában pályázók között a legnagyobb, köszönhető ez a vállalkozásnak minősülő farmergazdaságoknak.

3. ábra. A pályázók megoszlása vállalkozási formájuk alapján főkategóriánként

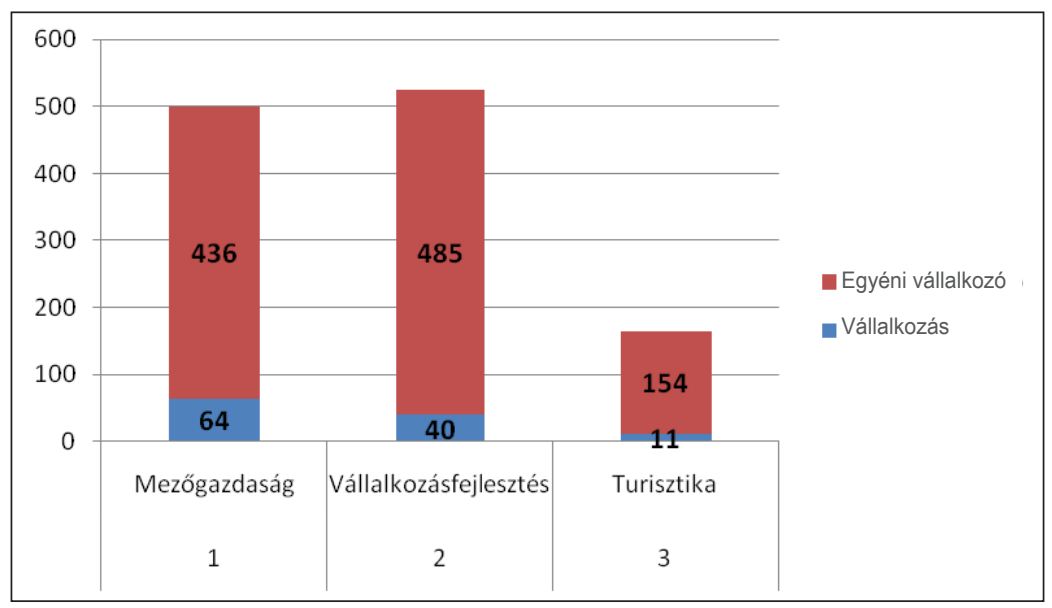

Forrás: Saját szerkesztés 


\section{TEMATIKUS TANULMÁNYOK - Kárpátalja társadalma}

A pályázatok értékelése során vállalkozás kategóriában legalább 50 pontot, mezőgazdasági pályázat esetében minimum 52,7 pontot, míg turisztikánál 41,5 pontot kellett elérni a „támogatott státusz” eléréséhez. Az ez alatti pontszámmal rendelkező pályázók, amennyiben a pályázat nem ütközött a pályázati kiírásban megfogalmazott feltételek valamelyikébe, „forrás függvényében támogatott” csoportba került. A forrásfüggvényes pályázók mindegyike támogatásban részesült, ők három hónap késéssel, 2017 márciusában köthettek támogatói szerződést az irodával.

A pályázatok támogatottsága 89 \%-os aktivitást mutat. ${ }^{14}$ Megállapítható tehát, hogy nagyon magas a támogatottak részaránya a beküldött pályázatok közül, amely pályázat megfelelt a formai és tartalmi követelményeknek, az támogatott lett. A pályázati kiírás viszont nem egyértelmúsítette, hogy egy pályázó az adott ciklusban hány pályázati kérelmet nyújthat be. Emiatt voltak, akik mindhárom kategóriában benyújtották pályázataikat. Miután a nyertes pályázatok kiértesítésre kerültek, a pályázónak döntenie kellett arról, hogy melyik kategóriát kívánja tovább vinni, ugyanis nem lehetett támogatást átvenni több területen. A döntés utáni helyzetről publikus információhoz viszont már nem tudtunk jutni, ami kis részben torzítja az értékelést. A pályázati kiírás erre vonatkozó része 2017-ben pontosítva lett, s idén már nem lehetett, csak egy kategóriába beadni a támogatási igényt.

A vállalkozások karakterét, nemzetközi jellegét tekintve jelentős befolyással nem bírt az értékelésnél, bár a pályázati űrlapon be kellett jelölni az esetleges export/ importtevékenységet és anyaországgal tartott szakmai kapcsolatot, valamint azt dokumentumokkal alá is kellett támasztani. Az ilyesfajta határon átnyúló viszonyt alátámasztani tudó vállalkozók alacsony száma és a kiírás alapján benyújtott alátámasztó dokumentumok típus-meghatározásának zavara miatt a végső értékelésnél e tevékenységek nem jártak többletponttal.

A 2016-os pályázati ciklusról elmondható, hogy a pályázati kiírás több pontja nem egyértelmű. A benyújtási időszak egy hónapja alatt a kiírás többször is megváltoztatásra került. A program kommunikációja nem volt megfelelő, a Kárpátalja különböző részein tartott tájékoztató gyűlések nem kerültek előzetes meghirdetésre pl. az alapítvány weboldalán. Emiatt sokan nem értesültek időben a lehetőségről.

A pályázatok értékelése során 35 pont a pontozó teljesen szubjektív véleményétől függően volt megszerezhető. Például, 0-tól 20-ig terjedő skálán kellett értékelni a következőket: „pályázó részletes képet adott az eddigi tevékenységéről, rendelkezik szakmai tapasztalattal (már meglévő alapokkal az adott tevékenység végzéséhez), vagy ha nem, akkor motivációja, vagy más figyelembe vehető okból kifolyólag alkal-

${ }^{14}$ A többi beadott pályázat „függvényében támogatott kategóriába” tartozó, melyeket két kiírt kategóriában nyújtottak be, amelyből végül ki kellett választani azt az egyet, amelyet meg szeretnének valósítani. Ez a csoport teszi ki a támogatásban részesültek $2 \%$-át. 
www. metszetek.unideb.hu

\section{TEMATIKUS TANULMÁNYOK - Kárpátalja társadalma}

mas a projekt megvalósítására. A projekt üzleti szempontú megalapozottsága, versenyképessége."

A külföldi gazdasági tevékenységet igazolók sem kaphatták meg az előzetes értékelési szempontokban megjelölt három többletpontot.

A támogatásban részesült pályázatoknak mezőgazdaságnál 52,5 pontot, vállalkozásfejlesztés esetében 50 pontot, turisztikánál viszont csupán 41,5 pontot kellett elérniük a 100 pontos értékskálán. Ezen minimum ponthatárok nem bírnak különösebb jelentőséggel, mivel amely pályázat formailag és tartalmilag megfelelt, vagyis nem volt a kiírás szövegével szembemenő, ha nem is érte el a minimumot, „forrás függvényében támogatottnak" minősítették, és három hónappal a támogatott pályázatok elszámolást követően, e vállalkozók mindegyike szerződhetett (6. sz. táblázat).

10. táblázat. A megítélt támogatások összege fő- és alkategóriánként (Ft)

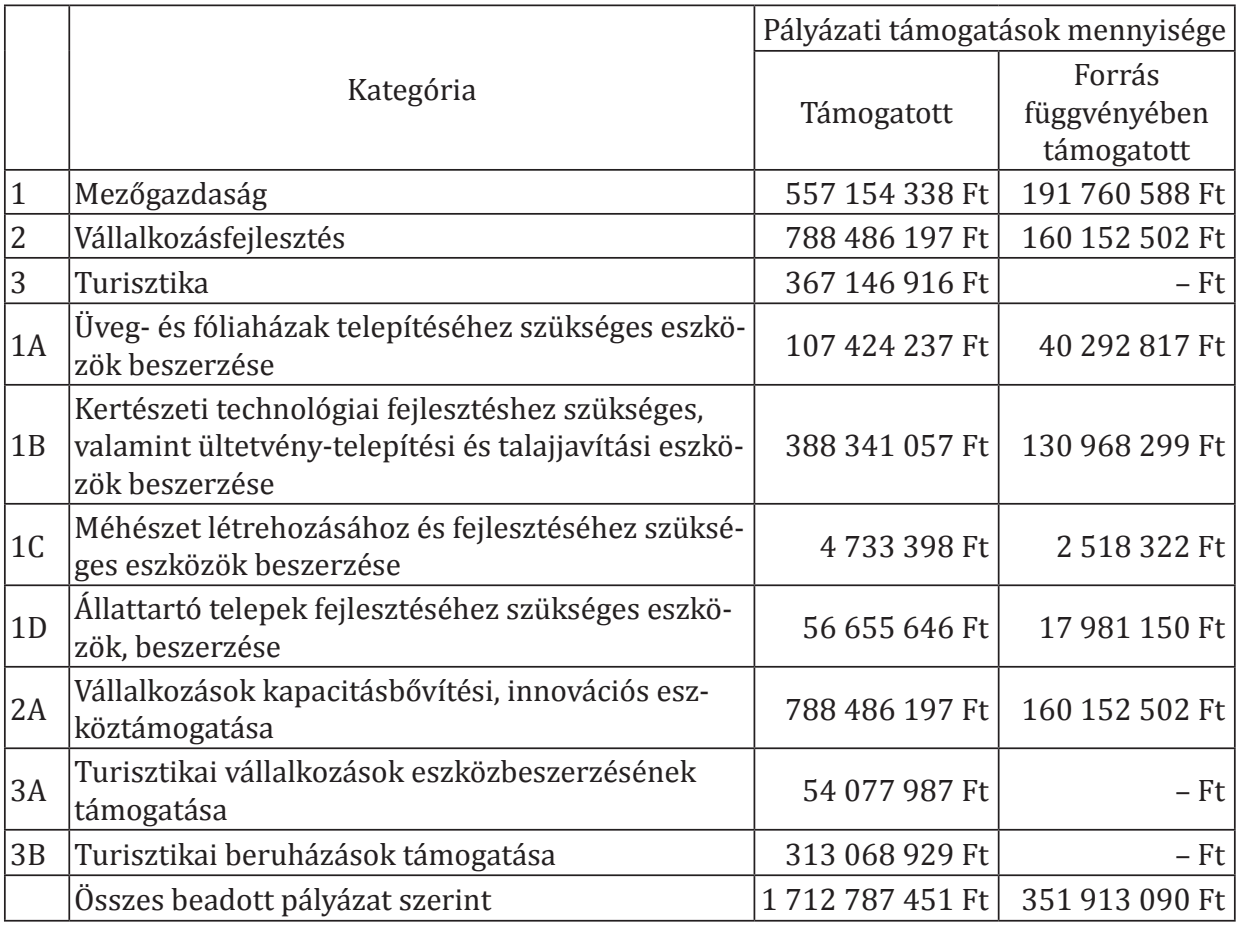

Forrás: Saját számítás az Egán Ede Jótékonysági Alapítvány adatai alapján

Átlagosan a benyújtott pályázatok 68 \%-a volt támogatva. A benyújtott pályázatok támogatottsága főkategóriánként a következőképpen alakult: a turisztikai pályázatoknál a pályázók 75,2\% részesült támogatásban és a támogatási összeg 21,4\%-át 


\section{TEMATIKUS TANULMÁNYOK - Kárpátalja társadalma}

kapták meg; a vállalatfejlesztésre jutott a legtöbb forrás (46,2\%), a támogatottság aránya 69,2\% volt; a mezőgazdasági pályázók közül 64,3\% részesült támogatásban, ami a pályázati keretösszeg 32,4\%-át tette ki.

Mivel a mezőgazdasági pályázati kategóriára 1100 M Ft volt előirányozva és csak 746 M Ft értékben volt támogatható pályázat (formailag és tartalmilag a pályázati kiírásnak megfelelő), ezért az Egán Ede Jótékonysági Alapítvány Kuratóriuma a pályázati kategóriák közötti összegek átcsoportosításáról döntött. Ennek megfelelően a fennmaradt összeget vállalkozásfejlesztésre csoportosították át. Ennek tudható be az, hogy az eredetileg tervezett 500 M Ft keretösszeget 937 M Ft-ra módosították.

Bár az első pályázati ciklus már lezárult és a második ciklus is aktív fázisba lépett, a Gazdaságfejlesztési programmal kapcsolatban több kérdés és probléma felvetődik, melyek a jövőben megoldásra szorulnak. Ezen hiányosságok a következők:

1. Az előre kitűzött kifizetési intervallumok folyamatosan tolódtak, ami azt eredményezte, hogy voltak olyan pályázók, akiknek az eszközbeszerzésre kiutalt összegeket csak 2017 márciusában folyósították. Ez ahhoz vezetett, hogy a pályázók egy része az eredeti ártól drágábban kellett, hogy megvásárolja a kiválasztott eszközöket. Viszont voltak olyanok is, akik több hónapig bérleti díjat fizettek, s közben a gazdasági tevékenységüket nem tudták megkezdeni, mivel a berendezést még nem tudták megvásárolni és a termelési folyamatot elkezdeni. Külön ki kell emelni a magánvállalkozók speciális esetét, hisz ebben a helyzetben ők több havi fix adót (1760 UAH/hó) fizettek az ukrán államnak, s közben bevételekre nem tudtak szert tenni.

2. A 2016-ban részesült pályázók között voltak olyanok, akik a pályázat beadásához képest olcsóbb berendezést vettek, mivel a benyújtás és kifizetés között több hónap telt el, ami árváltozást eredményezett. Az ilyen helyzet azt eredményezte, hogy a nyertes pályázók nem tudtak elszámolni a támogatás összegével, hisz a pályázati kiírás nem tartalmaz olyan opciót, amely a fel nem használt összeg visszautalásának gyakorlati megvalósításáról szólna. Emiatt a következő, 2017-es pályázati ciklusban ezek a pályázók nem pályázhattak, őket automatikusan kizárták belőle. Az ilyen rövidlátás ahhoz vezethet a jövőben, hogy: a) a nyertes pályázók sem fognak arra összpontosítani, hogy az olcsóbb berendezést vásárolják meg (hisz ez szankcionálandó), ami a Magyar Kormány által biztosított források felhasználásának alacsony hatékonyságát eredményezi; $b$ ) a pályázók mindenképp (legális vagy illegális pénzügyi-számviteli megoldásokat alkalmazva) dokumentálni fogják a számukra megítélt összegek 100\%-os felhasználását, vagyis a pályázókat ezáltal sarokba szorítva, alternatívát nem látva, a csalásra ösztönözik; c) téves látszatot keltenek a pályázatok zökkenőmentes lebonyolításáról és igazságos elosztásáról.

3. A turisztikai beruházásoknál visszaélések voltak tapasztalhatók azon személyeknél, akik egy háztartásban élve egyszerre több pályázatot adtak be és 


\section{TEMATIKUS TANULMÁNYOK - Kárpátalja társadalma}

részesültek támogatásban. A visszaélés abban nyilvánult meg, hogy a két vállalkozó (pl. férj és feleség) a bérbe adandó két épület közül az egyik pályázat összegéből a családi házat újította fel és a továbbiakban nem szándékoztak azt bérbe kiadni a turisták számára. Vagyis az ilyen pályázók számára nyújtott támogatás nem fejt ki gazdaságélénkítési hatást.

4. A pályázatok elbírálásánál hiányosságokat lehet megállapítani, hisz vannak rá precedensek, hogy a pályázatok értékelését egyetemen tanuló diákok is végezték, mely kérdésessé teszi a több millió forint odaítélésének szakmaiságát. Az is kérdéses, hogy bármilyen tudományterületen megszerzett egyetemi szintű diploma megléte elégséges-e ahhoz, hogy ilyen komoly pénzügyi eszközök lehívására meghirdetett pályázatok elbírálásánál a bírálók szakmailag kompetensnek mondhatóak.

5. Mivel a jelenlegi ukrajnai jogszabályok értelmében egy személy évente max 2600 UAH megfelelő adózási kötelezettség nélküli vissza nem térítendő támogatásban részesülhet, ezért fel fog merülni a kérdés a pályázók adókötelességével kapcsolatban az elnyert összegek után, ami jelenleg 19,5\%-t (18\% SZJA és 1,5\% hadiadó) jelent.

6. Bár a program alapjául szolgáló Egán Ede Gazdaságfejlesztési Tervben az eszközállomány fejlesztése mellett szerepelt a vállalkozók és gazdák képzésének terve is, a gyakorlati megvalósítás során ez elmaradt. Ezen hiányosságot tekintjük a program „Akhilleusz-sarkának”, mivel véleményünk szerint a szellemi tőke a termelési-értékesítési folyamat sikerében legalább ugyanolyan fontosságú, mint a materiális eszközállomány.

Az Egán Ede programról jelenleg csak alapvető megállapításokat tehetünk, mivel a támogatások folyósítása óta még nem telt el annyi idő, hogy a gyakorlati hasznosulás következményeit vizsgáljuk. Mivel a támogatottak jelentős része egyéni vállalkozás és ezek változásáról, foglalkoztatás bővüléséről és egyéb gazdasági aktivitásukról nem jelent meg a Statisztikai Hivatal hivatalos eredménye, így egzakt értékelést a változásokról ma még nehéz lenne tenni.

Érthető módon a vállalkozók számára a vissza nem térítendő támogatások lehívása a legelőnyösebb formája a forrásteremtésnek, hisz nincs semmilyen kötelezettségük a felhasznált források hatékonyságát tekintve. Ha 0\% kamat mellett tudnának hitelhez folyamodni a vállalkozások, akkor egyszerre kiszűrhetőek a fiktív tevékenységet vivő pályázók, és így támogathatóak lennének a valós vállalatfejlesztésre törekvő vállalkozók, vállalkozások. A múltban már voltak ilyen pozitív tapasztalok.

Az anyaország tekintetében a 90-es években voltak az Új Kézfogás Alapítványnak mikrohitelei, kamattámogatása. Ennek hatékonyságát és hasznosulását tekintve a szakértők véleménye erősen megoszlik. A legtöbben egyetértenek azzal, hogy a kisösszegú támogatások és a mikrohitel program nem hozta meg a várt hatást, vi- 


\section{TEMATIKUS TANULMÁNYOK - Kárpátalja társadalma}

szont a kamattámogatást azért találták hasznosnak, mert a program hárította az ukrajnai kamatkockázatot, viszont az eltérő jogrend közötti hézag sem nyilvánulhatott meg, mivel a hitel behajtásáról a helyi bankoknak és hatóságoknak kellett gondoskodniuk. A program rövid életű volt, $s$ ha hasznos is lehetett volna, kellő kifutási időt nem kapott (Czaller - Csite - Geambașu 2016). 1992 és 1999 között az Alapítvány 250,5 M Ft-ot utalt Kárpátaljára, ami a támogatások 21,6\%-át tette ki. ${ }^{15}$

Az ukrán pénzügyi helyzetet ismerve nem csoda, hogy a vállalkozók a hitelekkel szemben egységesen gyanakvóak. Ha a forráskihelyezést a Magyar Kormány által is feltőkésített és pénzügyi tevékenységet a saját irányítása alatt végezné, akkor a vállalkozói bizalom is megnőne az ilyen jellegű hitelek iránt.

\section{Következtetések, javaslatok}

Jelen tanulmány célja az volt, hogy általános helyzetképet festve bemutassa Kárpátalja határmenti régiójában a vállalkozások helyzetét, szekunder adatokból kiindulva (statisztikai hivatalok publikációi), valamint empirikus kutatások felhasználásával, melyek olyan hiánypótló területet dolgoztak fel, mint a kárpátaljai magyar ajkú vállalkozások karakterének és sajátosságainak jellemzése.

A makrogazdasági és politikai környezetben megtalálható hektikusság szinte folyamatosan jellemezte az országot, így térségünket is. Mivel határmenti, periférikus területről van szó, így a hullámok később és kisebb intenzitással jelentkeztek, viszont ez pozitív értelemben is igaz, a gazdasági felemelkedés is kevésbé volt szembetűnő (elmaradt infrastrukturális fejlesztések, beruházások hátrébb sorolása stb.).

Az üzleti vállalkozások tekintetében országosan az egyéni, mikro- és kisvállalkozások csökkenése volt tapasztalható az elmúlt időszakban. Erre vonatkozóan statisztikák még csak részben mutatják a tendenciát, mivel az idei évtől bevezetett adóváltoztatások hatottak úgy, hogy tömegesen zárták be azokat a vállalkozásokat, melyek vegetatív módon működtek. Ez egyrészt tisztulást hoz, viszont a csökkenés mögött reál visszaesés is mutatkozott, ami a foglalkoztatottak számának és a reálbérnek az esésében is testet öltött.

A vállalkozások megoszlása a különböző ágazatok között jellemzi a térség gazdasági szerkezetének sajátosságát is. Egyrészt azt, hogy domináns a kisvállalkozások száma a közepes és főleg a nagyvállalatok összehasonlításában. A mikro vállalatok nagy része mezőgazdaságban érdekelt, így összességében túlsúlyban van a mezőgazdasági termelés. Mivel ez az ágazat elaprózódott birtokszerkezettel, alacsony tőkésítéssel működik, így a termelés hatásfoka is alacsony. Ezért jellemzően a bérszínvonal is elmarad a kívánatostól, ami az ágazatból való folyamatos, napjaikban egyre intenzívebb munkaerő-kiáramlásában mutatja meg negatív hatását.

15 Új Kézfogás Közalapítvány, http://epa.uz.ua/02100/02169/00013/990419.htm 


\section{TEMATIKUS TANULMÁNYOK - Kárpátalja társadalma}

A helyzetelemzés bemutatja azt is, hogy nem homogén módon oszlik meg a vállalkozások száma és termelékenységi ereje a megye egyes járásai között. Legjelentősebbek az ungvári és munkácsi járások. Viszont a legmagyarabb beregszászi járás kedvezőtlenebb adatokat mutat.

A tanulmány második fejezetében a hitelszövetkezetek bemutatása kapcsán azt a következtetést vonhatjuk le, hogy az országos átlaghoz képest a hitelszövetkezetek száma és intenzitása jelentősebb Kárpátalján. Ezt az eredményt nem a határmenti magyar lakta régió produkálta, hanem főleg az iparilag fejlettebb városok. A szövetkezeti hitelintézet gazdaságélénkítő szerepe elsősorban abban áll, hogy a tagok közötti bizalmi kapcsolat, a jogi keretek megléte és annak betartása segíti a tőkefelhalmozást, az egyének és intézményi tagság megtakarítását, majd pedig célirányos befektetések kivitelezését. A térség alacsony bevételei és jövedelmei közepette fontos, hogy minél több csatornán neveljük a külső tőkebevonást és annak befektetési hatásfokát. A jól működő hitelszövetkezetek ilyen területen hiánypótlók.

A magyar lakta térségben nem müködik ilyen hitelszövetkezet. Ennek okai: alacsony a vállalkozói aktivitás, a régi vállalkozások csalódtak a közös tevékenységekben, a magyar ajkú vállalkozók nehezebben igazodnak ki az ukrán szabályozási rendszerekben, valamint alacsony volt a megtakarítási hajlandósági ráta (mivel alacsony jövedelmezőséggel müködnek a cégek).

Javaslatunk, hogy az Egán Ede program keretén belül érkező tőkeinjekció hatását próbálja a döntéshozó testület a jövőben mikrohitelezési konstrukció formájában is továbblendíteni. Ez azt jelenti, hogy ne csak vissza nem térítendő támogatások, valamint nagyberuházások vegyes konstrukcióban elérhető hitelei, hanem a kicsik számára is elérhető hiteleket is biztosítson.

Központi kezdeményezésre szövetkezetek alakítása lenne indokolt. Egyrészt olyan formában, hogy szakágazatonként termelési és értékesítési szövetkezetek (TÉSZ) megalakításával, másrészt kimondottan pénzügyi alapon együttműködő vállalkozói csoportok létrehozásával (hitelszövetkezetek).

A tanulmány utolsó egységében bemutatott támogatási rendszer segítségével átláthatjuk, hogy az utóbbi évben milyen vállalkozásfejlesztési támogatások érkeztek Magyarország irányából a profitorientált vállalkozások számára. Ez azért jelentős változás, mivel ezt megelőzően ilyen jellegű pályázatokra nem volt lehetősége a kárpátaljai magyar gazdáknak, vállalkozóknak. Első évben lehetett is látni egy kis bizalmatlanságot, viszont egyre jelentősebb a pályázók köre, felbuzdulva az „első fecskék" sikerén.

Az utolsó fejezetben bemutattuk a kritikai észrevételeinket, amivel szeretnénk hozzá járulni a rendkívül jó és fontos kezdeményezés minél hatékonyabb megvalósításához. Ezek között egyrészt technikai jellegű hibákra hívtuk fel a figyelmet (kifizetési intervallumok csúszása, kódolva van, hogy a vállalkozó valamilyen „trükközésen" keresztül tegyen eleget a bürokratikus feltételeknek, több esetben nem 


\section{TEMATIKUS TANULMÁNYOK - Kárpátalja társadalma}

ösztönöz a költséghatékonyságra), másrészt strukturális hiba merült fel a turisztikai szektorban kiírt pályázatok kapcsán. Ezt a 2017-es évben nem is indították el, így viszont kimarad a fejlesztésből az az ágazat, amely stratégiai jelentőséggel bír(hat) Kárpátalja gazdaságában.

A tanulmány szerzői, mint Kárpátalján élő és a térség jövőjét figyelő, a fejlődésében érdekelt személyek, fontosnak tartjuk, hogy ez a remek kezdeményezés tovább folytatódjon a jövőben. Igazi hatását akkor tudjuk majd mérni, ha legalább 5 éves periódus eredményeit tudjuk vizsgálni. Viszont az első évek következtetései alapján már ma javasoljuk a kisebb kiigazításokat, majd pedig olyan stratégiai változtatásokat, mint:

- Kis- és mikrohitelek biztosítása a helyi kisvállalkozások számára;

- Szövetkezeti rendszer kialakítása (hitelszövetkezetek és termelési-értékesítési szövetkezetek);

- Célzott nagyberuházások támogatása (feldolgozó ipar);

Minden támogatási rendszer kezdeti fázisában jelentkeznek ún. gyermekbetegségek. Bízunk benne, hogy tanulmányunk is hozzájárul a hibák kiküszöbölésének segítségébe. Ennél is fontosabb, hogy a folyamat ne álljon meg, és a javasolt fejlesztések, s akár új ötletek is belekerüljenek a rendszerbe, hogy még hatékonyabb és a kárpátaljai magyarság, valamint az össztársadalom hasznát szolgálják.

\section{Összegzés}

A tanulmány célja az volt, hogy hangsúlyosan a hitelszövetkezetek szerepének bemutatásával általános képet fessen a kárpátaljai vállalkozások, főleg a határmenti magyar lakta térség üzleti környezetéről, sajátos helyzetéről. Kiemelt szerepet kapott az Egán Ede gazdaságfejlesztési program, ill. egyéb olyan magyarországi támogatási struktúrák bemutatása, mely ennek az üzleti környezetnek a fejlődését hivatott elősegíteni.

A kutatási módszer bemutatásánál ismertettük a célokat és azokat a módszereket, amit felhasználtunk jelen tanulmány elkészítésénél. Ezek között szerepel a statisztikai komparatív összehasonlítás, korreláció-elemzés, valamint a pénzügyi elemzéseknél ismert PEARS modell bemutatása. Dokumentumkutatás módszerét használva elemeztük a támogatási források sajátosságait, így mutattunk be általános helyzetképet a rendszer indulásától számítva napjainkig.

A tartalmi rész három fontos egységre bontható: 1. vállalkozások helyzetének ismertetése a statisztikai adatok tükrében; 2. a kárpátaljai hitelszövetkezetek bemutatás, összehasonlítva az országos adatokkal; 3. a vállakozásfejlesztésre célirányosan érkező magyarországi támogatási rendszer bemutatása és értékelése. 


\section{TEMATIKUS TANULMÁNYOK - Kárpátalja társadalma}

Az első részben az országos és megyei társadalmi-gazdasági paraméterek ismertetésével kezdtük az értékelést, majd a fókusz a helyi vállalkozói környezet bemutatására helyeződött át. Az értékelést a Statisztikai Hivatal jelentésére, részben pedig a közelmúltban megjelent, a kárpátaljai magyar vállalkozások helyzetét empirikus módszerekkel elemző tanulmány eredményeire alapozva valósítottuk meg.

A második tartalmi egységben összehasonlítottuk az ukrajnai és kárpátaljai hitelszövetkezetek sajátosságait. Bemutattuk a hatásfokukat és az ország szabályozási rendszerében megmutatkozó anomáliák káros hatását a rendszer egészére és a benne működő szövetkezeti tagságra.

Az utolsó egységet a magyarországi támogatási struktúra bemutatására szántuk. Elemeztük mind a teljes Kárpát-medencében futó külhoni magyar vállalkozásokat támogató programokat (fiatal vállalkozók és családi vállalkozók éve), mind a specifikus kárpátaljai programot, az Egán Ede gazdaságfejlesztési csomagot.

A tanulmány végén javaslattétellel élünk, amely nem csak a főbb következtetéseit foglalja össze a tanulmánynak, hanem akár a programok múködése kapcsán él kisebb kiigazítási javaslatokkal, vagy nagyobb strukturális változtatással.

Bízunk benne, hogy munkánk mind értékelésében, mind gyakorlati javaslataiban hozzájárul a gazdasági hatékonysághoz a kárpátaljai vállalkozások támogatásszerzése és felhasználása, valamint a jövőben összekapcsolása tekintetében a hitelszövetkezetek relációjában.

\section{Irodalom}

Az „Egán Ede” Kárpátaljai Gazdaságfejlesztési Központ” Jótékonysági Alapítvány pályázati eredménye egyéni vállalkozók, valamint mikro- és kisvállalkozások kapacitásbővítési, innovációs támogatására a mezőgazdaság területén.

https://www.eganede.com/mezogazdasag-eredmenyek.pdf (Utolsó letöltés: 2017. 10. 16.)

Az „Egán Ede” Kárpátaljai Gazdaságfejlesztési Központ” Jótékonysági Alapítvány pályázati eredménye egyéni vállalkozók, valamint mikro- és kisvállalkozások kapacitásbővítési, innovációs támogatására a turisztika területén.

https://www.eganede.com/turisztika-eredmenyek.pdf. (Utolsó letöltés: 2017. 10. 16.)

Az „Egán Ede” Kárpátaljai Gazdaságfejlesztési Központ” Jótékonysági Alapítvány pályázati eredménye egyéni vállalkozók, valamint mikro- és kisvállalkozások kapacitásbővítési, innovációs támogatására a vállalkozásfejlesztés területén.

https://www.eganede.com/vallalkozas-eredmenyek.pdf. (Utolsó letöltés: 2017. 10. 16.)

Az ukrajnai hitelszövetkezeti rendszer adatsorai. Ukrajnai Pénzügyi Szervezetek Nemzeti Bizottság 
www. metszetek.unideb.hu

\section{TEMATIKUS TANULMÁNYOK - Kárpátalja társadalma}

https://nfp.gov.ua/content/stan-i-rozvitok-kreditnih-spilok.html. (Utolsó letöltés: 2017.08.21.)

Az Ukrajnai Pénzügyi Szervezetek Nemzeti Bizottságának adatai https://nfp.gov.ua/content/stan-i-rozvitok-kreditnih-spilok.html. (Utolsó letöltés: 2017.06 .03$.

Bárdi, N. (2004): Tény és való. A budapesti kormányzatok és a határon túli magyarság kapcsolattörténete. Problémakatalógus. KALLIGRAM Könyvkiadó, Pozsony

Czaller, L. - Csite, A. - Geambasu, R. (szerk.) (2016): Megkapaszkodás, gyarapodás, bátorítás - jelentés a külhoni fiatal magyar vállalkozók helyzetéről 2016. Hétfa Kutatóintézet és Nemzetpolitikai Kutatóintézet.

Egán Ede Gazdaságfejlesztési Terv (2014) https://www.eganede.com/egan-ede-terv.pdf.: p. 65. (Utolsó letöltés: 2017. 08.24.)

Kárpátaljai Állami Statisztikai Szolgálat (2017): Jelentés a kárpátaljai vállalkozások számának alakulásáról 2016-ban.

http://www.ukrstat.gov.ua/operativ/operativ2013/fin/kp_ed/kp_ed_u/kp_ ed_u_2016.htm 2017. október 30. (Utolsó letöltés: 2017. 10.30.)

Tandem 2016 - Kárpátaljai szociológiai felmérés.

http://bgazrt.hu/_dbfiles/htmltext_files/2/0000000432/A5\%20tandem.pdf (Utolsó letöltés: 2017. 10.30.)

Tátrai, P. - Erőss, Á. - Kovály, K. (2016): Migráció és versengő nemzetpolitikák Kárpátalján az Euromajdan után. REGIO, 24, 3: 82-110.

Új Kézfogás Közalapítvány. http://epa.uz.ua/02100/02169/00013/990419.htm

Ukrajnai Állami Statisztikai Szolgálat (2017): Ukrajnai statisztikai jelentés 2016-ról. http://ukrstat.gov.ua/druk/publicat/kat_u/2017/zb/08/Ukr_cifra_2016_u.zip (Utolsó letöltés: 2017. 10.25.)

Wekerle-terv. http://www.kkvhaz.hu/cikk/338-wekerle-terv (Utolsó letöltés: 2017. 10.30.) 